$9-4-2018$

\title{
Administrative Constitutionalism and the Unity of Public Law
}

Matthew Lewans

University of Alberta

Follow this and additional works at: https://digitalcommons.osgoode.yorku.ca/ohlj

Part of the Administrative Law Commons, and the Constitutional Law Commons Article

\section{(c) (1) $(9)$}

This work is licensed under a Creative Commons Attribution-Noncommercial-No Derivative Works 4.0 License.

\section{Citation Information}

Lewans, Matthew. "Administrative Constitutionalism and the Unity of Public Law." Osgoode Hall Law Journal 55.2 (2018) : 515-556.

https://digitalcommons.osgoode.yorku.ca/ohlj/vol55/iss2/5

This Article is brought to you for free and open access by the Journals at Osgoode Digital Commons. It has been accepted for inclusion in Osgoode Hall Law Journal by an authorized editor of Osgoode Digital Commons. 


\title{
Administrative Constitutionalism and the Unity of Public Law
}

\begin{abstract}
Public law scholarship in the common law tradition often aims at elucidating a connection between law and constitutional values like equality, due process, and the rule of law. However, in their quest to reveal the morality of public law, common lawyers often focus their attention on judicial interpretations of constitutional values to the exclusion of other sources of constitutional jurisprudence. The author argues that the traditional fascination with courts as the primary or exclusive arbiters of constitutional values should be tempered and supplemented by recognizing the valuable contributions of administrative officials who interpret and enforce constitutional norms when exercising statutorily delegated legal authority. By drawing attention to the contributions of the Canadian Human Rights Commission and Tribunal in advancing equality rights, the author argues that recent decisions from the Supreme Court of Canada which recommend judicial deference to reasonable, proportionate, and contextually sensitive administrative decisions concerning human rights, instead of resorting reflexively to correctness review, will serve to strengthen the moral unity of Canadian public law.
\end{abstract}

\section{Keywords}

Administrative law; Constitutional law; Canada

Creative Commons License (c) (i) (9)

This work is licensed under a Creative Commons Attribution-Noncommercial-No Derivative Works 4.0 License. 


\section{Administrative Constitutionalism and the Unity of Public Law}

\section{MATTHEW LEWANS*}

Public law scholarship in the common law tradition often aims at elucidating a connection between law and constitutional values like equality, due process, and the rule of law. However, in their quest to reveal the morality of public law, common lawyers often focus their attention on judicial interpretations of constitutional values to the exclusion of other sources of constitutional jurisprudence. The author argues that the traditional fascination with courts as the primary or exclusive arbiters of constitutional values should be tempered and supplemented by recognizing the valuable contributions of administrative officials who interpret and enforce constitutional norms when exercising statutorily delegated legal authority. By drawing attention to the contributions of the Canadian Human Rights Commission and Tribunal in advancing equality rights, the author argues that recent decisions from the Supreme Court of Canada which recommend judicial deference to reasonable, proportionate, and contextually sensitive administrative decisions concerning human rights, instead of resorting reflexively to correctness review, will serve to strengthen the moral unity of Canadian public law.

I. STUNTING THE LIVING TREE.

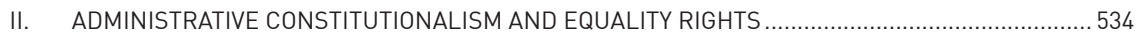

A. Administrative Constitutionalism and Parliamentary Responsibility ................................ 538

B. Administrative Constitutionalism And The Living Tree .............................................. 540

C. Administrative Constitutionalism Through Avoidance Of Mossop And Egan .................... 548

III. ADMINISTRATIVE CONSTITUTIONALISM AND THE UNITY OF PUBLIC LAW ..... 552

Associate Professor, University of Alberta. Thanks to Ashton Menuz for her excellent research assistance, and to David Dyzenhaus, Audrey Macklin, Eric Adams, Hillary Nye, and Anonymous Reviewer \#1 for their suggestions and constructive criticism. Comments are welcome at lewans@ualberta.ca. 
This decision [Obergefell $v$ Hodges] affirms what millions of Americans already believe in their hearts: When all Americans are treated as equal we are all more free.

My administration has been guided by that idea. It's why we stopped defending the so-called Defense of Marriage Act, and why we were pleased when the Court finally struck down a central provision of that discriminatory law. It's why we ended "Don't Ask, Don't Tell." From extending full marital benefits to federal employees and their spouses, to expanding hospital visitation rights for LGBT patients and their loved ones, we've made real progress in advancing equality for LGBT Americans in ways that were unimaginable not too long ago. ${ }^{1}$

CONVERSATIONS ABOUT THE UNITY OF PUBLIC LAW often focus on a fundamental relationship between law and underlying constitutional values like due process, liberty, equality, and the rule of law. ${ }^{2}$ Lawyers have good reason to explore this connection, because it elucidates the normative underpinning for morally legitimate interactions between the state and individuals who are subject to the exercise of state power. And because these values are often woven into the very fabric of the law (the constitutional provisions, legislation, regulations, common law principles, and international laws which guide official decision making) they have enormous potential to improve the lives of ordinary people, especially those who belong to political minority groups.

However, while lawyers devote considerable time and energy to parsing judicial opinions in their quest to reveal the inner morality of public law, they tend to overlook administrative law as a valuable source of constitutional jurisprudence. Fascination with the judiciary runs deep in the common law psyche, but it comes at the risk of eliding an important distinction between the general moral grounding of constitutional values and one particular apparatus for vindicating them. This confusion crops up in powerful doctrinal aphorisms, which portray the judiciary as the primary or exclusive agent for vindicating constitutional principles, ${ }^{3}$ which are often echoed and amplified by legal theorists

1. President Barack Obama, "Remarks by the President on the Supreme Court Decision on Marriage Equality" (Speech delivered at the White House Rose Garden, 26 June 2015), online: <www.whitehouse.gov/the-press-office/2015/06/26/ remarks-president-supreme-court-decision-marriage-equality $>$.

2. See e.g. David Dyzenhaus, ed, The Unity of Public Law (Oxford: Hart, 2004).

3. See e.g. Dr Bonham's Case (1610), 8 Co Rep 107a, 77 ER 638 at 652:

[T] he common law will controul Acts of Parliament, and sometimes adjudge them to be utterly void: for when an Act of Parliament is against common right and reason, or repugnant, or impossible to be performed, the common law will controul it, and adjudge such Act to be void [internal numbering omitted].

See also Marbury v Madison, 5 US (1 Cranch) 137 at 177 (1803):

It is emphatically the province and the duty of the judicial department to say what the law is. Those who apply the rule to particular cases, must of necessity, expound and interpret the rule. If two laws conflict with each other, the courts must decide on the operation of each. 
who champion the judiciary as the primary or exclusive means for upholding the rule of law. ${ }^{4}$

For example, even though William Blackstone recognized that the legitimacy of lex non scripta "rests entirely upon general reception and usage," he argued that interpretive disagreements should be determined "by the judges in the several courts of justice" whom he called "the depositaries of the law; the living oracles, who must decide in all cases of doubt." Thus, despite acknowledging that the legitimacy of the common law is rooted in the moral convictions of the demos, Blackstone argued that the substantive content of those principles should be determined exclusively by an elite class of public officials. And as Jeremy Bentham was keen to point out, ${ }^{6}$ this aspect of Blackstone's theory is problematic because it asserts that judges should preserve the "symmetry" of the common law even to the point of resisting popular legislative reforms designed to enhance public welfare. ${ }^{7}$ While Bentham's utilitarian critique of Blackstone's common law theory focused on an institutional tension between legislatures and courts in the eighteenth century, it foreshadowed a similar tension between courts and administrative agencies in the twentieth century as legislatures relied increasingly on administrative officials to assist with the project of building a more just society.

The institutional hubris embedded in legal theories which portray the judiciary as the exclusive agent of constitutionalism is unfortunate, because instead of conceiving legislatures, courts, and administrative agencies as partners in the ongoing project of interpreting and implementing constitutional values

4. William Blackstone, Commentaries on the Laws of England, vol 1 (London: Cavendish, 2001). See also AV Dicey, Introduction to the Study of the Law of the Constitution, 10th ed (London: Macmillan \& Co, 1964) ch XII [Dicey, Study of the Law of the Constitution]; Ronald Dworkin, Taking Rights Seriously (London: Duckworth, 1977) ch 4 [Dworkin, Taking Rights Seriously].

5. Blackstone, supra note 4 at 35 .

6. Jeremy Bentham, A Fragment on Government, (Cambridge: Cambridge University Press, 1988) 97-105.

7. Blackstone, supra note 4 at 5-6:

The mischiefs that have arisen to the public from inconsiderate alterations in our laws, are too obvious to be called in question; and how far they have been owing to the defective education of our senators, is a point well worthy the public attention. The common law of England has fared like other venerable edifices of antiquity, which rash and unexperienced workmen have ventured to new-dress and refine, with all the rage of modern improvement. Hence frequently its symmetry has been destroyed, its proportions distorted, and its majestic simplicity exchanged for specious embellishments and fantastic novelties. For, to say the truth, almost all the perplexed questions, almost all the niceties, intricacies, and delays (which have sometimes disgraced the English, as well as other courts of justice), owe their original not to the common law itself, but to innovations that have been made in it by acts of parliament; "overladen" (as Sir Edward Coke expresses it) with provisos and additions, and many times on a sudden "penned or corrected by men of none or very little judgment in law." 
that enjoy widespread public support, they habitually imagine administrative officials as bogeymen-recalcitrant threats to the rule of law that must be controlled through strict judicial oversight. One symptom of this tendency is the prevalent argument ${ }^{8}$ that the law of judicial review should be fractured so that administrative decisions concerning matters of public policy merit judicial deference, ${ }^{9}$ while decisions involving constitutional rights or values should be reassessed by judges according to their own interpretive standards. ${ }^{10}$

In this article, I will offer an alternative paradigm for bolstering the unity of public law, one that is more congenial to administrative constitutionalismthe phenomenon whereby administrative officials interpret and implement constitutional values while exercising statutorily delegated authority. ${ }^{11}$ Put simply, my argument accepts Blackstone's premise that the moral grounding of constitutional values "rests entirely upon general reception and usage," but rejects his inference that "judges in the several courts of justice ... must decide in all cases of doubt."12 Instead, I argue that the licence to interpret and implement constitutional values extends to administrative officials, which entails that judges should respect administrative decisions concerning constitutional

8. See e.g. Dworkin, Taking Rights Seriously, supra note 4, ch 4; Cass R Sunstein, "Beyond Marbury: The Executive's Power to Say What the Law Is" (2006) 115:9 Yale LJ 2580; William N Eskridge Jr \& Lauren E Baer, "The Continuum of Deference: Supreme Court Treatment of Agency Statutory Interpretations from Chevron to Hamdan" (2008) 96:4 Geo LJ 1083; Michael Taggart, "Proportionality, Deference, Wednesbury" [2008]:3 NZLR 423; Jason Ne Varuhas, "Against Unification" in Mark Elliott \& Hanna Wilberg, eds, The Scope and Intensity of Substantive Review: Traversing Taggart's Rainbow (Oxford, Hart, 2015) 91.

9. See e.g. Chevron, USA Inc v Natural Resources Defense Council, Inc, 467 US 837 (1984); Canadian Union of Public Employees, Local 963 v New Brunswick Liquor Corporation, [1979] 2 SCR 227, 25 NBR (2d) 237

10. See e.g. Solid Waste Agency of Northern Cook County v US Army Corps of Engineers, et al, 531 US 159 (2001); Williams v Babbitt, 115 F (3d) 657 (9th Cir, 1997); Slaight Communications Inc v Davidson, [1989] 1 SCR 1038, 59 DLR (4th) 416; Canada (Attorney General) v Mossop, [1993] 1 SCR 554, 100 DLR (4th) 658 [Mossop]; Multani v Commmission scolaire Marguerite-Bourgeoys, 2006 SCC 6, [2006] 1 SCR 256; Sunstein, supra note 8 at 2609.

11. See e.g., Sophia Z Lee, "From the History to the Theory of Administrative Constitutionalism" in Nicholas R Parrillo, ed, Administrative Law From the Inside Out: Essays on Themes in the Work of Jerry L. Mashaw (Cambridge: Cambridge University Press, 2017) 109; Bertrall L Ross II, "Embracing Administrative Constitutionalism" (2015) 95:2 BUL Rev 519; Sophia Z Lee, "Race, Sex, and Rulemaking: Administrative Constitutionalism and the Workplace, 1960 to the Present" (2010) 96:4 Va L Rev 799; Gillian E Metzger, "Administrative Constitutionalism" (2013) 91:7 Tex L Rev 1897; Sophia Z Lee, The Workplace Constitution from the New Deal to the New Right (New York: Cambridge University Press, 2014).

12. Blackstone, supra note 4 at 35 . 
matters provided that they are rendered in a fair, transparent, and reasonably justified manner. Thus, instead of fragmenting the law of judicial review so that administrative decisions concerning public policy matters are scrutinized according to a different conceptual standard than decisions involving constitutional issues, I argue in favour of a unified legal framework for judicial review that seeks to foster legitimate modes for synthesizing abstract constitutional principles with a dynamic social context across a broad range of administrative action. ${ }^{13}$

However, instead of pitching my arguments at a purely theoretical level, I want to advance them by examining developments concerning equality rights on the ground, especially recent advancements in constitutional jurisprudence regarding equality rights. ${ }^{14}$ While this issue has attracted the attention of journalists, political scientists, and constitutional lawyers over the past thirty years, much of that commentary still tends to be preoccupied with decisions of apex courts. For example, when the Supreme Court of the United States held in Obergefell $v$ Hodges that state legislation which does not recognize the validity of gay marriages violates the due process and equal protection clauses of the Fourteenth Amendment, ${ }^{15}$ commentators ${ }^{16}$ immediately highlighted the genealogy of the majority opinion beginning with the nadir of Bowers $v$ Hardwick, ${ }^{17}$ to a turning point in Romerv Evans, ${ }^{18}$ through the dramatic overruling of Bowers in Lawrence $v$ Texas, ${ }^{19}$ to the demise of the Defense of Marriage Act in United States $v$ Windsor. ${ }^{20}$ While this doctrinal genealogy is true so far as it goes,

13. David Dyzenhaus, "The Politics of Deference: Judicial Review and Democracy" in Michael Taggart, ed, The Province of Administrative Law (Oxford: Hart, 1997) 279 [Dyzenhaus, "The Politics"]; David Dyzenhaus, "Law as Justification: Etienne Mureinik's Conception of Legal Culture" (1998) 14:1 SAJHR 11 [Dyzenhaus, "Justification"]; Mark Walters, "Respecting Deference as Respect: Rights, Reasonableness and Proportionality in Canadian Administrative Law" in Mark Elliott \& Hannah Wilberg, eds, The Scope and Intensity of Substantive Review: Traversing Taggart's Rainbow (Oxford: Hart, 2015).

14. For more theoretically inclined arguments, see David Dyzenhaus, "Constituting the Rule of Law: Fundamental Values in Administrative Law” (2002) 27:2 Queen's LJ 445); Jerry L Mashaw, "Norms, Practices, and the Paradox of Deference: A Preliminary Inquiry into Agency Statutory Interpretation" (2005) 57:2 Admin L Rev 501; Kenneth A Bamberger, "Normative Canons in the Review of Administrative Policymaking” (2008) 118:1 Yale LJ 64; Murray Hunt, "Against Bifurcation" in David Dyzenhaus, Murray Hunt \& Grant Huscroft, eds, A Simple Common Lawyer: Essays in Honour of Michael Taggart (Oxford: Hart, 2009) 99.

15. Obergefell $v$ Hodges, 135 S Ct 2584 (2015).

16. See e.g. Elizabeth B Cooper, "The Power of Dignity" (2015) 84:1 Fordham L Rev 3.

17. 478 US 186 (1986) [Bowers].

18. 517 US 620 (1996).

19. 539 US 558 (2003).

20. 570 US 744 (2013); Defense of Marriage Act, Pub L No 104-199, 110 Stat 2419 (1996). 
it is blinkered insofar as it overlooks important legislative and administrative decisions which foreshadowed critical shifts in equality rights jurisprudence. More specifically, it ignores important legislative and administrative decisions animated by conscientious, substantive interpretations of constitutional equality rights. President Barack Obama highlighted these decisions in his Rose Garden speech delivered on the morning Obergefell was released: extending federal hate crimes legislation to protect victims who have been abused because of their sexual orientation, ${ }^{21}$ issuing a presidential directive to extend hospital visitation rights to LGBT patients, ${ }^{22}$ extending employment benefits to gay federal employees, ${ }^{23}$ repealing "Don't Ask, Don't Tell," ${ }^{24}$ and instructing the Department of Justice to stop defending section 3 of the Defense of Marriage Act. ${ }^{25}$

I will argue that President Obama's comments highlighting the valuable contributions of administrative constitutionalism shed light on parallel developments in Canada. ${ }^{26}$ As in the United States, the legal narrative concerning equality rights in Canada is too often preoccupied with judicial opinions, especially those from the Supreme Court of Canada; ${ }^{27}$ and like the US Supreme

21. Matthew Shepard and James Byrd, Jr Hate Crimes Prevention Act, 18 USC $\S 249$ (2009).

22. Presidential Memorandum from the White House to the Secretary of Health and Human Services on Respecting the Rights of Hospital Patients to Receive Visitors and to Designate Surrogate Decision Makers for Medical Emergencies (15 April 2010), online: <obamawhitehouse.archives.gov/the-press-office/ presidential-memorandum-hospital-visitation>.

23. Presidential Memorandum from The White House to the Heads of Executive Departments and Agencies on the Extension of Benefits to Same-Sex Domestic Partners of Federal Employees (2 June 2010), online: <obamawhitehouse.archives.gov/the-press-office/ presidential-memorandum-extension-benefits-same-sex-domestic-partners-federal-emplo>; Sophia Lee, "Administering the Constitution in 2020" (25 September 2009), Balkinization (blog), online: <balkin.blogspot.ca/2009/09/administering-constitution-in-2020.html>.

24. Don't Ask, Don't Tell was an executive directive issued by the Department of Defense, which prohibited discrimination against closeted LGB military personnel, but barred openly LGB persons from serving in the military. Department of Defense Directive No 1304.26, encl 1, $\S$ E1.2.8.1-E1.2.8.2 (21 December 1993); Don't Ask, Don't Tell Repeal Act of 2010, Pub L No 111-321, 124 Stat 3515 (2010), codified at 10 USC $^{\S} 654$.

25. United States, Department of Justice (Office of Public Affairs), "Statement of the Attorney General on Litigation Involving the Defense of Marriage Act" (23 February 2011), online: <www.justice.gov/opa/pr/ statement-attorney-general-litigation-involving-defense-marriage-act>.

26. See generally Jody Freeman, "Defining Family in Mossop v. DSS: The Challenge of Anti-Essentialism and Interactive Discrimination for Human Rights Litigation" (1994) 44:1 UTLJ 41.

27. See e.g. Brenda Cossman, "Lesbians, Gay Men, and the Canadian Charter of Rights and Freedoms” (2002) 40:3\&4 Osgoode Hall LJ 223. 
Court, those judicial opinions reveal a series of false steps ${ }^{28}$ and equivocation, ${ }^{29}$ but ultimately culminate in landmark rulings which extend equality rights despite under-inclusive and discriminatory legislation..$^{30}$ I want to supplement this narrative by illustrating how human rights commissions and tribunals championed equality rights during the $1980 \mathrm{~s},{ }^{31}$ and how these administrative decisions expanded employment rights for LGB individuals and offer an interpretive groundwork for rehabilitating the Supreme Court of Canada's equality rights jurisprudence under section 15 of the Charter of Rights and Freedoms. ${ }^{32}$ This history shows not only that administrative officials are capable of interpreting constitutional values in a rationally defensible manner that reveals their moral purpose within a dynamic social context, ${ }^{33}$ but also reveals how administrative constitutionalism in Canada was frustrated through heavy-handed approaches to judicial review which assumed that judges ought to review administrative decisions concerning human rights according to a correctness standard. More importantly, it demonstrates that more recent Supreme Court of Canada decisions holding that administrative decisions concerning constitutional values are worthy of judicial deference ${ }^{34}$ can serve to strengthen, rather than weaken, the moral unity of public law. ${ }^{35}$

My argument will unfold in three Parts. In Part I, I will briefly interrogate the obscure, but highly influential, living tree doctrine of Canadian constitutional

28. See e.g. Andrews v Ontario (Minister of Health) (1988), 64 OR (2d) 258, 49 DLR (4th) 584 (SC); Vogel v Manitoba (1992), 79 Man R (2d) 208, 90 DLR (4th) 84, (QB); Layland v Ontario (Minister of Consumer \& Commercial Relations) (1993), 14 OR (3d) 658, 104 DLR (4th) 214 (Div Ct).

29. Egan $v$ Canada, [1995] 2 SCR 513, 124 DLR (4th) 609 [Egan].

30. Vriend v Alberta, [1998] 1 SCR 493, 156 DLR (4th) 385 [Vriend]; $M v H$, [1999] 2 SCR 3, 43 OR (3d) 254.

31. Annette Nierobisz, Mark Searl \& Charles Théroux, Human Rights Commissions and Public Policy: The Role of the Canadian Human Rights Commission in Advancing Sexual Orientation Equality Rights in Canada, (Ottawa: Canadian Human Rights Commission, 2008), online: $<$ www.chrc-ccdp.gc.ca/eng/content/human-rights-commissions-and-public-policy-rolecanadian-human-rights-commission-advancing $>$.

32. Canadian Charter of Rights and Freedoms, Part I of the Constitution Act, 1982, being Schedule B to the Canada Act 1982 (UK), 1982 c 11, s 15 [Charter].

33. Doré v Barreau du Québec, 2012 SCC 12 at para 54, [2012] 1 SCR 395 [Doré].

34. Ibid; Loyola High School v Quebec (Attorney General), 2015 SCC 12, [2015] 1 SCR 613. See also David Mullan, "Administrative Tribunals and Judicial Review of Charter Issues After Multani" (2007) 21 NJCL 127; Matthew Lewans, "Administrative Law, Judicial Deference, and the Charter" (2014) 23:2 Const Forum Const 19.

35. But see Audrey Macklin, "Charter Right or Charter-Lite? Administrative Discretion and the Charter” (2014) 67 SCLR (2d) 561. 
law, which is traditionally construed so as to empower judges, but not administrative officials, to articulate and enforce a large and liberal interpretation of constitutional values. While the living tree metaphor is generally understood to promote an expansive interpretation of constitutional norms, I will argue that the institutional limitations traditionally ascribed to the living tree doctrine have served to stunt the development of equality rights in Canada. In Part II, I will advance my critique of this doctrinal trend by examining how Canadian human rights agencies articulated an expansive interpretation of equality rights in order to extend them to LGB individuals. By urging legislatures to enlarge statutory human rights protections, articulating a progressive and purposive interpretation of their enabling legislation, and limiting the precedential force of common law authorities premised upon an originalist interpretation of their enabling legislation, human rights agencies discharged their statutory mandate in a manner which was aligned with their underlying commitment to the constitutional value of equality. In addition, I will show how Parliament and Canadian courts frequently frustrated the efforts of human rights agencies by either ignoring their contributions or reviewing their decisions according to a correctness standard of review. Finally, in Part III, I will briefly consider the implications this case study has for reforming the law of judicial review so as to unleash the interpretive potential of administrative constitutionalism.

\section{STUNTING THE LIVING TREE}

When Canadian lawyers explain how to sustain and advance constitutional values over the course of time, they often begin with a ritual exhortation, that the Constitution is a "living tree capable of growth and expansion within its natural limits." ${ }^{\text {6 }}$ The living tree doctrine has become such a fixture in Canadian constitutional law that when the Supreme Court of Canada held unanimously in 2004 that the Constitution Act, 1867 did not entrench a nineteenth-century conception of heterosexual marriage, it declared it to be "one of the most fundamental principles of Canadian constitutional interpretation: that our Constitution is a living tree which, by way of progressive interpretation,

36. Edwards v Canada (Attorney General) (1929), [1930] AC 124, [1930] 1 DLR 98 at 106-07 (PC) $[E d w a r d s]$, Lord Sankey (Edwards is commonly referred to as the "Persons case"). See generally, Justice Ian Binnie, "Constitutional Interpretation and Original Intent" in Grant Huscroft \& Ian Brodie, eds, Constitutionalism in the Charter Era (Markham: LexisNexis Canada, 2004) 345. 
accommodates and addresses the realities of modern life." ${ }^{37}$ Therefore, in much the same way as the Judicial Committee of the Privy Council concluded in 1905 that Parliament's jurisdiction over interprovincial "undertakings" under section 91 of the Constitution Act, 1867 included the power to regulate telephones (even though that technology did not exist when the Constitution was first written), ${ }^{38}$ the Supreme Court of Canada concluded in 2004 that Parliamentary jurisdiction over "marriage" could accommodate a twenty-first century definition of marriage which includes same-sex couples.

But despite its vaunted status, the lawyerly understanding of the living tree doctrine glosses over significant institutional and doctrinal limits that have stunted the development of Canadian equality rights jurisprudence. More specifically, it glosses over the way in which judicial review has been conceived traditionally as a means for consolidating the political authority of legislatures and courts, often at the expense of more broadly-based, democratic discourse regarding the content of constitutional principles.

Part of this problem stems from the obscure character of the living tree metaphor itself (and others like it). ${ }^{39}$ Its intuitive appeal stems from its ability to convey the paradoxical nature of constitutional law: While the Canadian Constitution is rooted in a particular institutional history, its principles are expressed at a level of abstraction that requires its adherents to interpret and adapt them in light of a dynamic socio-economic environment. So instead of assuming that the content of constitutional principles can or should be defined by a sovereign legislator, constitutional assembly, or Supreme Court, the living tree metaphor projects the idea that the meaning of constitutional principles emerges through open-ended interpretive discourse. However, the metaphor itself does not address important methodological and institutional questions regarding the task of constitutional interpretation. One particularly pressing question is whether the judiciary is exclusively entitled (i.e., by virtue of its evidentiary process, political independence, or legal expertise) to determine the content of constitutional principles or whether constitutional interpretation should be governed by a democratic ethos whereby the meaning of constitutional principles

37. Reference re Same-Sex Marriage, 2004 SCC 79 at para 22, [2004] 3 SCR 698.

38. Toronto Corporation v Bell Telephone Co of Canada (1904), [1905] AC 52, CR [13] AC 361 (PC).

39. See e.g. Otto Neurath, "Foundations of the Social Sciences" in International Encyclopedia of Unified Science (Chicago: University of Chicago Press, 1944) 1 at 47; Ronald Dworkin, "Law's Ambitions for Itself" (1985) 71:2 Va L Rev 173 [Dworkin, "Law's Ambitions"]; Ronald Dworkin, Law's Empire (London: Fontana Press, 1986) ch 7 [Dworkin, Law's Empire]. 
emerges through sustained, evidence-based inquiry and reasoned debate within a community of free and equal citizens. ${ }^{40}$

Interestingly, one of the most influential champions of judicial review in the last century, Ronald Dworkin, equivocates on this point. On the one hand, in Taking Rights Seriously he relies upon a problematic distinction between arguments of principle (like the right to equality instantiated by anti-discrimination statutes) that "justify a political decision by showing that the decision respects or secures some individual or group right," and arguments of policy (like subsidies for aircraft manufacturers) that advance "some collective goal of the community as a whole." ${ }^{41} \mathrm{He}$ argues that the content of principles should not be determined through the legislative process "because an argument of principle does not often rest on assumptions about the nature and intensity of the different demands and concerns distributed throughout the community." ${ }^{22}$ Therefore, Dworkin proposes that they be determined by "[a] judge who is insulated from the demands of the political majority" because he is "in a better position to evaluate the argument." ${ }^{43}$ To underline this point, he employs a suggestive heuristic device for determining the content of legal principles-a superhuman judge named Hercules, who is capable of articulating a legal argument which both fits a political community's institutional history and provides the best substantive moral justification for it. ${ }^{44}$ Thus, it seems that Dworkin was committed (at least initially) to the position that judges should ultimately determine the meaning of constitutional principles, which implies that judicial deference to administrative decisions concerning such issues would be tantamount to an abdication of judicial responsibility.

But in his later work, Dworkin articulates a more nuanced perspective, arguing that although the judiciary plays an important role in the constitutional project, it does not necessarily have primary or exclusive interpretive authority over constitutional principles. Sometimes Dworkin gestures towards this more nuanced view by deploying the first-person plural pronoun (instead of a mythical judge) as the agent of constitutional interpretation. For example, after setting out his theory of law in his McCorkle lecture, Dworkin observes that:

$[w]$ e debate about justice and fairness through the institutions we have, seeking, as part of that debate, to reform these institutions as we use them, acknowledging that

40. Jürgen Habermas, Between Facts and Norms: Contributions to a Discourse Theory of Law and Democracy, translated by William Rehg (Cambridge: MIT Press, 1996) at 3-5.

41. Dworkin, Taking Rights Seriously, supra note 4 at 107. For an insightful critique of Dworkin's principle/policy distinction, see Dimitrios Kyritsis, "Principles, Policies and the Power of Courts" (2007) 20:2 Can JL \& Jur 379.

42. Dworkin, Taking Rights Seriously, supra note 4 at 110.

43. Ibid.

44. Ibid; Dworkin, Law's Empire, supra note 39. 
any institutional structure we achieve is provisional, that no decision of majority or executive or court is right just because it has been taken, or right just because it must be respected so long as it stands. ${ }^{45}$

Later, when advocating for a 'moral reading' of the US Constitution in Freedom's Law, Dworkin acknowledges that such a project is consistent with various institutional arrangements, including those that reserve an interpretive role for other branches of government. Thus, he insists that the moral reading of the constitution "is a theory about how certain clauses of some constitutions should be read-about what questions must be asked and answered in deciding what those clauses mean and require. It is not a theory about who must ask these questions, or about whose answer must be taken to be authoritative." ${ }^{\prime 6}$ Finally, when he refines his theory in Justice in Robes Dworkin emphasizes the principle of 'legality,' which requires the state to exercise its coercive power in accordance with standards previously established 'in the right way' —as the organizing principle for his legal theory. But instead of ascribing exclusive institutional responsibility for upholding the principle of legality, he simply states that it is inspired by two fundamental political values: procedural fairness and substantive justice, which he says, "is the nerve of political justification." ${ }^{47}$

The bottom line is that despite advocating "a result-driven rather than a procedure-driven standard" ${ }^{38}$ for distributing institutional responsibility, Dworkin pulls up short of Blackstone's assertion that judges "must decide in all cases of doubt." ${ }^{49}$ At important junctures, especially his more recent work, Dworkin argues that law's content is to be gleaned through open, fair, and reasonably justified discourse about what those principles mean under the circumstances without speculating about whose answer must be taken to be authoritative. ${ }^{50}$ In this respect, Dworkin's more recent account of legality resonates with Jürgen Habermas's proceduralist understanding of $l a w^{51}$ in which the legitimacy of legality is rooted in a communicative arrangement whereby legal subjects are

45. Dworkin, "Law's Ambitions," supra note 39 at 187.

46. Ronald Dworkin, Freedom's Law: The Moral Reading of the American Constitution (Cambridge, Mass: Harvard University Press, 1996) at 34 [Dworkin, Freedom's Law].

47. Ronald Dworkin, Justice in Robes (Cambridge, Mass: The Belknap Press of Harvard University Press, 2006) at 171 [Dworkin, Justice in Robes].

48. Dworkin, Freedom's Law, supra note 46 at 34.

49. Blackstone, supra note 4 at 35 .

50. Thus, Jürgen Habermas asks, "Who represents the authority of the constitution best, the citizenry as a whole or the judge? Dworkin swings back and forth between the perspective of citizens, from which judicial duties are legitimated, and the perspective of a judge, who claims to be in a privileged position in virtue of her expertise." See Habermas, supra note 40 at 222 .

51. Ibid at 427. 
"able to examine whether a contested norm meets with, or could meet with, the agreement of all those possibly affected." 52 Expressed in Dworkinian terms, the legitimacy of legality is underpinned by a process which is procedurally fair (i.e., because it is open, accessible, and responsive to individuals who are subject to the law) and substantively just (e.g., because its normativity is purchased by offering reasons which are rationally acceptable in light of constitutional values instead of resorting solely to the coercive power of the state). Thus, the purpose of judicial review is not to provide judges with opportunities for exercising an exclusive licence for defining and disseminating the meaning of constitutional principles, but rather to buttress the legitimacy of the legal order by ensuring that any interpretation of constitutional principles offered by state actors is procedurally fair and rationally acceptable in the public domain. According to such an approach, administrative institutions are not incorrigible threats to the rule of law, which must be brought to heel by a judiciary with unique access to constitutional truths, but partners in the quest to determine the meaning of constitutional principles in light of a diverse and complicated body of evidence and human experience..$^{53}$

While Dworkin's philosophical account of constitutional interpretation may be equivocal at points, the doctrine of judicial review in Canada is much more lopsided. At the time the "Persons case" 54 was decided, the prevailing constitutional theory inherited from A.V. Dicey ${ }^{55}$ held that the legislative, judicial, and administrative branches of government performed analytically distinct roles: the legislature had exclusive authority to make new law, the judiciary had exclusive control over how to interpret law, and the executive was responsible for implementing the law whose content would be determined by the legislature and the judiciary. ${ }^{56}$ According to this theory, the main point of judicial review was to shore up the authority of the legislature and the judiciary to determine the content of the law, and guard against prospect that administrative officials might do likewise. ${ }^{57}$ In this vein, Dicey famously declared that the concept of droit administratif was "utterly unknown to the law of England," ${ }^{88}$ because the tasks of

52. Ibid at 104. See also David Dyzenhaus, "The Legitimacy of Legality” (1996) 46:1 UTLJ 129

[Dyzenhaus, "Legitimacy of Legality"]; Dyzenhaus, "Justification," supra note 13.

53. Dyzenhaus, "The Legitimacy of Legality," supra note 52, 160-179.

54. Supra note 36. Edwards is commonly referred to as the "Persons case."

55. Dicey, Study of the Law of the Constitution, supra note 4.

56. David Dyzenhaus, "Formalism's Hollow Victory" (2002) 2002:4 NZLR 525;

Edwards, supra note 36.

57. David Dyzenhaus, Hard Cases in Wicked Legal Systems: Pathologies of Legality, 2nd ed (Oxford: Oxford University Press, 2010) at 187 [Dyzenhaus, Hard Cases].

58. Dicey, Study of the Law of the Constitution, supra note 4 at 121. 
legislating and legal interpretation were performed exclusively by Parliament and the "ordinary courts." 59

But because Diceyan constitutional theory drew inspiration from both John Austin's positivist theory of law and Blackstone's anti-positivist theory of the common law tradition, it motivated two very different conceptions of judicial review. The first conception, which regarded the principle of Parliamentary sovereignty as "the dominant characteristic of our political institutions," buttressed Parliament's legal authority by construing statutes strictly in relation to historical facts about legislative intent. ${ }^{60}$ The second conception, which regarded judges as the exclusive guardians of the rule of law, interpreted legislation against a background of unwritten common law principles. ${ }^{61}$ At times, this second conception was yoked to a libertarian understanding of the common law-one which assumed a limited role for the state so that interpersonal relationships were to be regulated by private law principles of contract and tort-so that judicial review served as a bulwark against the egalitarian and redistributive policies of the emerging welfare state. ${ }^{62}$ But at other times, it was expressed more ambiguously, so that the purpose of judicial review was to ensure the substantive coherence of the law while remaining agnostic about its underlying ideological character. ${ }^{63}$ Despite these differences, it is important to note that these interpretive positions are not necessarily mutually exclusive. Even more importantly, the upshot from the perspective of administrative law is more or less the same, because the prospect that administrative interpretations of law might warrant a degree of judicial deference is strictly limited on multiple fronts - by an originalist interpretation of legislative intent, a libertarian understanding of judicial responsibility to

59. See HW Arthurs, "Rethinking Administrative Law: A Slightly Dicey Business" (1979) 17:1 Osgoode Hall LJ 1 at 6.

60. Dicey, Study of the Law of the Constitution, supra note 4 at xxxvi.

61. Ibid at 413-14.

62. AV Dicey, Lectures on the Relation Between Law \& Public Opinion in England, 2nd ed (London: Macmillan, 1914) at xxiii-xciv, 303-310, 361-98. See also John Wills, "The McRuer Report: Lawyers' Values and Civil Servants' Values” (1968) 18:4 UTLJ 351 [Willis, "McRuer Report"].

Parliament is supreme legislator, but from the moment Parliament has uttered its will as lawgiver, that will becomes subject to the interpretation put upon it by the judges of the land, and the judges, who are influenced by the feelings of magistrates no less than by the general sprint of the common law, are disposed to construe statutory expectations to common law principles in a mode which would not commend itself either to a body of officials, or to the House of Parliament, if the Houses were called upon to interpret their own enactments (Dicey, Study of the Law of the Constitution, supra note 4 at 413-14).

63. Dyzenhaus, Hard Cases, supra note 57 at 187. 
preserve the primacy of the common law, or the assumption that the judiciary is exclusively responsible for maintaining the substantive coherence of the law (however defined).

All of these approaches to judicial review cropped up to varying degrees when the Canadian judiciary responded to legislative initiatives to expand human rights protections prior to 1982 . The first case study in this respect is the Canadian Supreme Court's Bill of Rights jurisprudence. ${ }^{64}$ While the scope of the Canadian Bill of Rights is limited and not constitutionally entrenched, Prime Minister John Diefenbaker nevertheless considered it to be his signature human rights achievement because he believed it would dramatically alter the manner in which federal law was made, interpreted, and administered. Thus, in his speech introducing the Bill of Rights to Parliament he declared confidently that "[ $t]$ here can be no doubt that this Act, when passed, will greatly strengthen the hand of the Courts." ${ }^{65}$

Unfortunately, Diefenbaker's bold prediction proved to be mistaken. ${ }^{66}$ Part of the problem was that instead of articulating a large and liberal interpretation of equality rights, the Supreme Court of Canada held repeatedly that the Bill of Rights was originally intended to only protect those rights that were conventionally recognized in 1960 when the legislation was first promulgated. ${ }^{67}$ Furthermore, to the extent that the Court did interpret the right to equality, it held that the Bill of Rights only guaranteed the right to "formal" equality (which Dicey defined as "the universal subjection of all classes to one law administered by the ordinary Courts") ${ }^{68}$ as opposed to the broader notion of "substantive" equality (whereby individuals would be entitled to be treated by the state with equal concern and respect). ${ }^{69}$

64. Canadian Bill of Rights, SC 1960, c 44 [Bill of Rights].

65. The Rt Honourable John G Diefenbaker, "Address on the nation's business" (Ottawa: Office of the Prime Minister, 30 June 1960), online: <www.collectionscanada.gc.ca/primeministers/ h4-4052-e.html>.

66. Berend Houvis, "The Legacy of the Supreme Court of Canada's Approach to the Canadian Bill of Rights: Prospects for the Charter" (1982) 28:1 McGill LJ 31.

67. Robertson and Rosetanni $v$ The Queen, [1963] SCR 651 at 654, 41 DLR (2d) 485. See WS Tarnopolsky, "A New Bill of Rights in the Light of the Interpretation of the Present One by the Supreme Court of Canada" in Special Lectures of the Law Society of Upper Canada: The Constitution and the Future of Canada (Toronto: Richard de Boo, 1978) 161 at 181-191; Hovius, supra note 66 at 39-44 (further discussing the Supreme Court of Canada's "frozen concepts" reading of the Bill of Rights).

68. Dicey, Study of the Law of the Constitution, supra note 4 at 114.

69. See e.g. Dworkin, Taking Rights Seriously, supra note 4 at 272-78. 
For example, when the Court was asked to consider whether section 12(1)(b) of the Indian Act - which stripped women, but not men, of their Indian status if they married a non-Indian-infringed the guarantee of equality before the law under section 1(b) of the Bill of Rights, Justice Ritchie (writing for the majority) declared that "the meaning to be given to the language employed in Bill of Rights is the meaning which it bore in Canada at the time when the Bill was enacted." ${ }^{\prime 70}$ Furthermore, he cited Dicey as authority for the proposition that the right to equality protected by the Bill of Rights did not "invoke the egalitarian concept exemplified by the 14th Amendment of the U.S. Constitution" ${ }^{\text {"11 }}$ but ensured only the "equal subjection of all classes to the ordinary law of the land as administered by the ordinary courts." 72 Therefore, so long as Parliament provided a legal code for regulating male and female registered Indians, and any interpretive dispute was determined by ordinary courts, it was irrelevant whether the purpose or practical effect of section 12(1)(b) discriminated against Indian women. The Court's failure to adopt a large and liberal conception of equality rights in this case (and others) $)^{73}$ explains why women's rights activists advocated for a more explicit, belt-and-suspenders formulation of equality rights when the text of the Charter was finalized in $1982 .{ }^{74}$ And even then, the road towards realizing equality rights has been rather rocky. ${ }^{75}$

70. Attorney General of Canada v Lavell, [1974] SCR 1349 at 1365, 38 DLR (3d) 481.

71. Ibid.

72. Ibid at 1366 [emphasis in original].

73. See also Bliss v Attorney General of Canada, [1979] 1 SCR 183, 92 DLR (3d) 417.

74. Michael Mandel, The Charter of Rights and the Legalization of Politics in Canada (Toronto: Thompson Educational, 1994) at 376-78. Section 15 of the Charter now states:

15(1) Every individual is equal before and under the law and has the right to the equal protection and equal benefit of the law without discrimination and, in particular, without discrimination based on race, national or ethnic origin, colour, religion, sex, age, or mental or physical disability.

(2) Subsection (1) does not preclude any law, program or activity that has as its object the amelioration of conditions of disadvantaged individuals or groups including those that are disadvantaged because of race, national or ethnic origin, colour, religion, sex, age or mental or physical disability (Charter, supra note 32, s 15).

75. See e.g. Jonnette Watson Hamilton \& Jennifer Koshan, "Adverse Impact: The Supreme Court's Approach to Adverse Effects Discrimination under Section 15 of the Charter" (2015) 19:2 Rev Const Stud 191; Jennifer Koshan, "Under the Influence: Discrimination Under Human Rights Legislation and Section 15 of the Charter" (2014) 3 Can J Hum Rts 115; Jennifer Koshan \& Jonnette Watson Hamilton, “The Continual Reinvention of Section 15 of the Charter" (2013) 64 UNBLJ 19; Bruce Ryder, "The Strange Double Life of Canadian Equality Rights" (2013) 63 SCLR (2d) 261. 
The second case study concerns judicial review of the decisions of human rights boards and commissions during this same period. Between 1962 and 1979, Parliament and the provincial legislatures began introducing human rights codes authorizing independent administrative agencies (human rights commissions, boards, and tribunals) to investigate, conciliate, mediate, litigate, and adjudicate discrimination complaints as well as develop government policy and educate the public about the importance of human rights initiatives. ${ }^{76}$ The impetus for these administrative reforms was partly to redress judicial decisions that provided legal cover for overt racism in the context of contractual dealings concerning housing, employment, and the provision of public services. ${ }^{77}$ By delegating authority to administrative officials drawn from the ranks of government, academia, churches, and social activists, these administrative regimes provided a more accessible, efficient, and effective means for expanding human rights protections to groups and individuals who were vulnerable to discriminatory treatment. ${ }^{78}$

Nevertheless, judicial review of human rights decisions remained heavy handed and, consequently, undermined the efficacy of these regulatory regimes well into the twenty-first century. Prior to 1979, the law of judicial review gave judges a broad licence to interfere with administrative decisions. Judges were entitled to correct any error of law so long as the error could be detected on the face of the record; and even if an administrative decision was protected by a privative clause, judges could nevertheless intervene to correct any 'jurisdictional' error of law. But because judges could make "jurisdictional error" mean almost

76. Dominique Clément, "Renewing Human Rights Law in Canada" (2017) 54:4 Osgoode Hall LJ 1311.

77. See e.g. Christie v The York Corporation (1939), [1940] SCR 139 at 142, [1940] 1 DLR 81 (this is a case in which a majority of the Court held that a tavern owner was legally entitled to refuse service to Black customers because of a general legal principle that granted him "complete freedom of commerce"). For historical commentary on the case, see James W St G Walker, "Race", Rights and the Law in the Supreme Court of Canada (Toronto: Osgoode Society of Canadian Legal History and Wilfred Laurier University Press, 1997) ch 3; Eric M Adams, "Errors of Fact and Law: Race, Space, and Hockey in Christie v York" (2012) 62:4 UTLJ 464.

78. R Brian Howe \& David Johnson, Restraining Equality: Human Rights Commissions in Canada (Toronto: University of Toronto Press, 2000) ch 2. 
anything, there were no meaningful limits on the extent to which judicial review might interfere with the substance of an administrative decision. ${ }^{79}$

One particularly influential case, Bell v Ontario Human Rights Commission, is emblematic of this broad licence to thwart administrative decisions and adjudicative processes. ${ }^{80}$ The case concerned a discrimination complaint filed by Carl McKay, a self-described "Black man from Jamaica," who had sought to rent an apartment from Kenneth Bell, a middle-aged white man who owned a three-storey house in Toronto. When McKay contacted Bell over the phone, Bell advised that the apartment was vacant and available to rent; but when McKay showed up personally to look at the apartment, Bell informed him that the apartment had already been let to someone else. Later that same day, one of McKay's white female friends made the same inquiry, at which time Bell offered to lease the apartment to her.

After conducting a preliminary investigation, the Ontario Human Rights Commission concluded that there was sufficient evidence to support McKay's complaint, and invited Bell to participate in the Commission's conciliation process. When Bell refused, the Commission referred the matter to a Board of Inquiry, chaired by Professor Walter Tarnopolsky, a law professor from the University of Windsor specializing in human rights law. However, before the hearing began Bell's lawyer objected that the Board lacked jurisdiction to hear the complaint, because in his view the apartment was not a "self-contained dwelling unit" within the meaning of section 3 of the Ontario Human Rights Code. ${ }^{81}$ In light of Bell's objection, the chair adjourned the proceedings in order to allow Bell the opportunity to seek a writ of prohibition.

In a decision granting the writ at first instance, the presiding judge declared (without citing any case authority) that "a man ... could exercise an untrammeled and biassed [sic] choice of those who dined at his table, or slept under his roof," 82 and declared that the "rights of a middle-aged white Canadian

79. See e.g. Anisminic Ltd v Foreign Compensation Commission (1968), [1969] 2 AC 147, [1969] 1 All ER 208 (HL); Metropolitan Life Insurance Co v International Union of Operating Engineers, [1970] SCR 425, 11 DLR (3d) 336. For criticism of the doctrine, see John Willis, "Three Approaches to Administrative Law: The Judicial, the Conceptual, and the Functional" (1935) 1:1 UTLJ 53; Bora Laskin, "Certiorari to Labour Boards: The Apparent Futility of Privative Clauses" (1952) 30:10 Can Bar Rev 986; Willis, "McRuer Report," supra note 62; Paul C Weiler, "The 'Slippery Slope' of Judicial Intervention: The Supreme Court and Canadian Labour Relations 1950-1970” (1971) 9:1 Osgoode Hall LJ 1; John Willis, "Canadian Administrative Law in Retrospect" (1974) 24:3 UTLJ 225.

80. [1971] SCR 756, 18 DLR (3d) 1 [Bell].

81. Ontario Human Rights Code, SO 1961-1962, c 93, s 3 [Code].

82. Rv Tarnopolsky, Ex parte Bell, [1969] 2 OR 709 at 713, 6 DLR (3d) 576 (SC). 
homeowner" were as important as any possessed by a "young, black, Jamaican tenant." ${ }^{33}$ After reviewing various dictionary definitions of "self-contained" as well as a smattering of Scottish case law concerning rent control legislation, the judge concluded solely on the basis of Bell's sworn affidavit that the Code did not apply because even though the apartment had separate living quarters, it was not "self-contained" because it did not have a separate entrance. However, the decision was overturned by the Court of Appeal for Ontario where Justice Laskin, writing for a unanimous court, recognized the Tribunal's role in interpreting the legislative provision in light of the Code's policy objectives of combatting racial discrimination. After noting that the question of whether Bell's apartment was a self-contained dwelling "depends on factual as well as constructional considerations," ${ }^{4}$ he concluded that "it is difficult to appreciate how the learned Judge could have proceeded to a determination when there was no record taken below bearing on the issue." 85 Accordingly, he remitted the case back to the Board of Inquiry for a proper hearing into the circumstances of the complaint.

Nevertheless, even in the absence of a proper evidentiary record the Supreme Court of Canada reinstated the Ontario High Court's original decision prohibiting the Board from hearing the complaint. ${ }^{86}$ While Justice Martland acknowledged that the declared purpose of the Code was to "seek to obtain equality of treatment without regard to race," he held that the Code was "specifically limited by its terms to dealing with such discrimination when it occurs in relation to defined fields of operation." ${ }^{\prime 77} \mathrm{He}$ went on to note that the Code "does not interfere with free expression of opinion," nor "prevent a householder from refusing to employ a domestic servant because of his antipathy to the race, colour or creed of a person seeking such employment." ${ }^{88}$ From this, Justice Martland inferred that the Code "does not prevent the owner of a house containing dwelling units which are not self-contained from refusing to lease such accommodation to anyone." ${ }^{89}$ Moreover, he disputed Justice Laskin's assertion in the court below that the Board should have been allowed to proceed to a hearing, saying that Bell "was not compelled to await the decision of the board on that issue before seeking to have

83. Ibid at 718 .

84. Rv Tarnopolsky, Ex parte Bell (1969), [1970] 2 OR 672 at 680, 11 DLR (3d) 658 (CA).

85. Ibid.

86. Bell, supra note 80 .

87. Ibid at 768 .

88. Ibid.

89. Ibid. 
it determined in a court of law by an application for prohibition, and the Court had jurisdiction to deal with the matter."

Justice Martland's reasoning in Bell is remarkable, because instead of interpreting the statute in light of its broader purpose and social context, the Court plucked a phrase from the statute, and defined that term in abstraction from concrete evidence concerning McKay's complaint. In doing so, the decision laid the basis for preliminary, jurisdictional challenges to human rights complaint referral processes for the next forty years, ${ }^{91}$ which would have a chilling effect on the complaint referral process regarding discrimination against LGB individuals. ${ }^{92}$

Finally, even when judicial reliance upon the doctrine of jurisdictional error began to wane gradually in the post-Charter era, judges continued to review the decisions of human rights agencies with little or no regard for how those agencies explained or justified their decisions. ${ }^{93}$ A classic example of this is Ontario Human Rights Commission v Simpson-Sears, a case in which the Supreme Court of Canada extended the broad, purposive interpretive approach it had begun to apply in

90. Ibid at 775 .

91. Halifax (Regional Municipality) v Nova Scotia (Human Rights Commission), 2012 SCC 10 at para 17, [2012] 1 SCR 364 [Halifax v Nova Scotia]. Bell remained good law in Canada until the Supreme Court of Canada finally overturned it in Halifax v Nova Scotia, ibid. Because judicial review of commission decisions declining to refer a complaint for a hearing, it is almost impossible to assess the chilling effect this decision actually had on the operation of provincial and federal human rights regimes.

92. See e.g. University of Saskatchewan v Saskatchewan (Human Rights Commission) (1976), 66 DLR (3d) 561, 3 WWR 385 (Sask QB) [University of Saskatchewan]. In University of Saskatchewan, the Saskatchewan Court of Queen's Bench issued a writ of prohibition to prevent the Saskatchewan Human Rights Commission from investigating a complaint of discrimination on the basis of lack of jurisdiction because the enabling legislation of the Commission did not explicitly prohibit discrimination on the ground of sexual orientation.

93. Alison Harvison Young, "Keeping the Courts at Bay: The Canadian Human Rights Commission and its Counterparts in Britain and Northern Ireland: Some Comparative Lessons" (1993) 43:1 UTLJ 65 at 73:

[I]n the current Canadian context, one could argue that the Charter has added respectability to the exercise of judicial power over human rights commissions by elevating the subject-matter of commission jurisdiction to quasi-constitutional status. Just as it seemed to Dicey to be 'natural, right and a matter of constitutional principle' that the ordinary courts should be supreme, it seems now natural and constitutionally required in substantive terms by the Charter that the ordinary courts be the guardians of human rights. The potential for extensive review is even greater in present day Canada, however, because the Charter gives the courts a mandate that is broader than the Dicey model, according to which review was, at least in principle, simply a matter of policing the legislative will.

See also Alison Harvison Young, "Human Rights Tribunals and the Supreme Court of Canada: Reformulating Deference" (1993) 13 Admin LR (2d) 206. 
Charter cases ${ }^{94}$ to its own interpretation of human rights legislation. ${ }^{95}$ However, while the Court extended its own interpretive licence as it pertained to human rights legislation, it also emphasized that the responsibility for articulating and defending such rights was the exclusive province of the judiciary. In a revealing passage Justice McIntyre declared:

It is not, in my view, a sound approach to say that according to established rules of construction no broader meaning can be given to the Code than the narrowest interpretation of the words employed. The accepted rules of construction are flexible enough to enable the Court to recognize in the construction of a human rights code the special nature and purpose of the enactment ... and give to it an interpretation which will advance its broad purposes. Legislation of this type is of a special nature, not quite constitutional but certainly more than ordinary — and it is for the courts to seek out its purpose and give it effect. ${ }^{96}$

Thus, while the Court was prepared to interpret the Ontario Human Rights Code expansively so that it captured adverse effects discrimination as well as intentional discrimination, it also instructed lower courts to measure the decisions of human rights agencies according to judicial standards of interpretation. The consequence of this has been that, while Canadian judges gradually began deferring to other specialized administrative agencies like Labour Boards, they persisted in keeping human rights agencies on a much shorter leash. ${ }^{97}$ And as we will see, this has often obstructed claims of marginalized groups who were seeking legal recognition of their equality rights.

\section{ADMINISTRATIVE CONSTITUTIONALISM AND EQUALITY RIGHTS}

On 17 August 1965, Everett Klippert pled guilty to four counts of "gross indecency," a day after confessing to an RCMP officer who was investigating a suspected case of arson that he had engaged in consensual sex with four different

94. See e.g. Hunter $v$ Southam Inc, [1984] 2 SCR 145, 11 DLR (4th) 641; Rv Big M Drug Mart Ltd, [1985] 1 SCR 295, 18 DLR (4th) 321.

95. Ontario Human Rights Commission v Simpson-Sears Ltd, [1985] 2 SCR 536,

23 DLR (4th) 321.

96. Ibid at 546-47 [emphasis added].

97. See e.g. British Columbia (Workers' Compensation Board) v Figliola, 2011 SCC 52, [2011] 3 SCR 422; Canada (Attorney General) v Mowat, 2011 SCC 53, [2011] 3 SCR 471. 
men since moving to Pine Point, Northwest Territories the year before. ${ }^{98}$ Even though the presiding judge imposed a three year term of imprisonment at the original sentencing hearing, the Crown prosecutor subsequently sought to have Klippert incarcerated indefinitely as a dangerous offender. ${ }^{99}$ This designation was reserved for criminals whom a court deemed "likely to cause injury, pain or other evil to any person" or "likely to commit a further sexual offence." ${ }^{100}$ And because homosexual acts were a criminal offence at the time, and Klippert had been forthright about his sexuality in interviews conducted by two court-appointed psychiatrists, the Crown's dangerous offender application was successful even though the psychiatrists described Klippert as a non-violent, practicing homosexual. ${ }^{101}$ In 1967, the Supreme Court of Canada confirmed Klippert's dangerous offender designation on the basis that he was "likely to commit further sexual offences of the same kind," despite acknowledging that "he never did cause injury, pain or other evil to any person and is not likely to do so in the future through his failure to control his sexual impulses." ${ }^{102}$

One month after the Court rendered its verdict, the federal Minister of Justice tabled a bill to modernize the Criminal Code by decriminalizing 'gross indecency' if committed in private between consenting adults over the age of twenty-one. Responding to public outrage over the Supreme Court of Canada's decision in Klippert, the Justice Minister at the time, Pierre Trudeau, famously told reporters that "there's no place for the state in the bedrooms of the nation," and declared the government's objective to align the "laws of the land" with the values of "contemporary society." 103 Unfortunately for Klippert, Trudeau's bill languished in Parliament for two years; and even after it was finally passed into law in 1969, Klippert inexplicably remained behind bars until 20 July 1971. ${ }^{104}$

98. John Ibbitson, "In 1965, Everett Klippert was sentenced to a life behind bars. His crime? Being gay," The Globe and Mail (27 February 2016) F1. See also Tom Warner, Never Going Back: A History of Queer Activism in Canada (Toronto: University of Toronto Press, 2002) at 46, 191-217. Klippert was never charged with arson, and none of Klippert's partners ever faced criminal charges for gross indecency.

99. Criminal Code, SC 1960-61, c 43, s 32 [Criminal Code].

100. Ibid.

101. Klippert v The Queen, [1967] SCR 822, 65 DLR (2d) 698.

102. Ibid at 833 .

103. Canadian Broadcasting Corporation, “There's no place for the state in the bedrooms of the nation” (21 December 1967), online: CBC Digital Archives <www.cbc.ca/player/ play/1811727781>. See also Warner, supra note 98 at 44-45.

104. Criminal Code, supra note 99. 
By the time he was finally released, Klippert had served a total of ten years in prison for simply being openly gay. ${ }^{105}$

On 20 July 2005-precisely thirty-four years to the day after Klippert was released from prison-Parliament legalized same-sex marriage. ${ }^{106}$ By that point, every human rights code in the country had been amended to prohibit discrimination on the basis of sexual orientation and Canadian courts had declared sexual orientation to be an analogous ground protected under section 15 of the Charter. The last province to formally amend its human rights legislation, Alberta, refused to prohibit discrimination on the ground of sexual orientation until 2009; however, in 1998 the Supreme Court of Canada held in Vriend v Alberta that Alberta's failure to extend to human rights protection to LGB persons infringed their equality rights under section 15 of the Charter. Accordingly, the Court concluded that the constitutional supremacy clause ${ }^{107}$ required Canadian courts to read protection from discrimination on the ground of sexual orientation into the provincial statute despite the Alberta government's refusal to amend the legislation. ${ }^{108}$

While Vriend is rightly regarded as a landmark in the Canadian constitutional law-a moment when the Supreme Court of Canada took the lead in delivering constitutional protection to an historically marginalized minority grouplawyers often overlook the substantial contributions of legislatures and human rights agencies to the advancement of equality rights prior to 1998. By 1977, five years before the Charter, Quebec had already amended its human rights legislation to include sexual orientation as a prohibited ground of discrimination, a move which immediately generated results for individuals who could have been prosecuted as criminals only a few years earlier. ${ }^{109}$ Thus, when the Catholic School Commission of Montreal refused to lease vacant premises to a community group dedicated to the advancement of lesbian and gay interests, the

105. Prior to moving to Pine Point, Klippert had previously served four years in prison for similar offences.

106. Civil Marriage Act, SC 2005, c 33.

107. See Constitution Act, 1982, being Schedule B to the Canada Act 1982 (UK), 1982, c 11. "The Constitution of Canada is the supreme law of Canada, and any law that is inconsistent with the provisions of the Constitution is, to the extent of the inconsistency, of no force and effect" (ibid, s 52(1)).

108. Vriend, supra note 30.

109. Didi Herman, Rights of Passage: Struggles for Lesbian and Gay Legal Equality (Toronto: University of Toronto Press, 1994) at 23-24. 
group successfully sought a court declaration that the School Commission had unlawfully discriminated against it. ${ }^{110}$

However, in the rest of English-speaking Canada, Parliament and the provincial legislatures failed to introduce similar statutory reforms. On 5 February 1981, approximately one year before the Canadian Charter of Rights and Freedoms came into force, Toronto police charged 286 men with indecency and prostitution during the infamous Toronto bathhouse raids-the largest mass arrest in Canada since Parliament invoked the War Measures Act during the 1970 October crisis shortly after the Front de Libération du Québec kidnapped a British diplomat and killed the deputy premier. While egregious police conduct during the bathhouse raids galvanized opposition to discriminatory conduct within Toronto's gay community, it would be another seventeen years before the Supreme Court of Canada would issue its decision in Vriend.

The important point is that outside of Quebec, LGB individuals and human rights agencies were largely abandoned by courts and legislatures in their struggle to advance equality rights from 1977-1998. What is particularly remarkable about this period is that human rights agencies managed to develop a progressive equality rights jurisprudence in the face of active and passive opposition from (1) legislatures which refused to amend their human rights legislation to prohibit discrimination on the basis of sexual orientation; (2) private individuals or institutions who launched legal proceedings to preserve their freedom (e.g., of contract, of speech, et cetera) to discriminate against LGB individuals and groups; and (3) superior courts which took a dim view of human rights agencies extending human rights protections to LGB individuals and groups when private litigants in class (2) sought judicial review of human rights agency decisions. ${ }^{111}$ By urging legislatures to enlarge statutory human rights protections, articulating a purposive interpretation of their enabling legislation, and refusing to ascribe gravitational force to common law precedents based on

110. L'Association ADGQv Catholic School Commission of Montreal (1979), [1980] CS 93, 112 DLR (3d) 230. See also Centre Homophile d'Aide et de Libération Inc v Le Progres du Saguenay Ltee (1979) unreported CP, Chicoutimi; Johnston c Rochette, [1982] CS 407, 3 CHRR D/1133.

111. See e.g. Gay Alliance Toward Equality v Vancouver Sun, [1979] 2 SCR 435, 97 DLR (3d) 577 (the decision of a Board of Inquiry appointed under the British Columbia Human Rights Code was quashed by the Supreme Court of Canada on the ground that the legislation did not extend to activities associated with freedom of the press); University of Saskatchewan, supra note 92 (the Court of Queen's Bench issued a writ of prohibition to prevent the Saskatchewan Human Rights Commission from investigating complaints on the basis that the enabling legislation did not protect individuals from discrimination on the ground of sexual orientation). 
an originalist interpretation of their enabling legislation, human rights agencies provided marginalized individuals with an opportunity to articulate and defend a progressive conception of equality rights. By doing so, human rights agents pricked the consciences of legislators, judges, and members of the broader public by offering cogent arguments on matters of constitutional principle that foreshadowed judicial decisions like Vriend. In what follows, I will examine how two particular human rights agencies - the Canadian Human Rights Commission and Tribunal — advanced a robust case for expanding the living tree constitution to protect equality rights at a time when the rest of society, including Parliament and the Supreme Court of Canada, failed to defend the constitutional principle of equality.

\section{A. ADMINISTRATIVE CONSTITUTIONALISM AND PARLIAMENTARY RESPONSIBILITY}

When the federal Human Rights Act first received Royal Assent in 1977, it excluded protection from discrimination on the basis of sexual orientation. ${ }^{112}$ This was no accident. In 1977, both the National Action Committee on the Status of Women ${ }^{113}$ and the Canadian Labour Congress ${ }^{114}$ appeared before the Standing Committee on Justice and Legal Affairs, and recommended that specific protection for LGB individuals be included in the legislation. Despite multi-party support for such a measure, the Liberal government's position was that only "well established" grounds of discrimination should be included in the Act. ${ }^{15}$ At the time, the Canadian Armed Forces, the RCMP, and the Department of External Affairs expressed concern that gay civil servants would pose a threat to public order and national security, because they were susceptible to blackmail from members of organized crime syndicates or foreign intelligence agencies. ${ }^{116}$ Put less charitably, Parliament refused to protect LGB individuals from discrimination in 1977 because the government of the day wished to preserve its ability to intimidate, interrogate, and dismiss LGB civil servants on the pretext of

112. Canadian Human Rights Act, SC 1976-77, c 33, s 3 [Human Rights Act].

113. House of Commons, Minutes of Proceedings and Evidence of the Standing Committee on Justice and Legal Affairs, 30th Parl, 2nd Sess, No 9 (26 April 1977) at 11.

114. House of Commons, Minutes of Proceedings and Evidence of the Standing Committee on Justice and Legal Affairs, 30th Parl, 2nd Sess, No 7 (29 March 1977) at 7.

115. House of Commons Debates, 30th Parl, 2nd Sess, No 6 (10 March 1977) at 11-12, 21.

116. Warner, supra note 98 at 26-28. 
preserving public order and security. ${ }^{117}$ But instead of declaring gay civil servants to be second-class citizens, it simply passed legislation that was silent on the issue. So while the Human Rights Act declared that "every individual should have an equal opportunity with other individuals to make for himself or herself the life that he or she is able and wishes to have" it only prohibited "discriminatory practices based on race, national or ethnic origin, colour, religion, age, sex or marital status." 118

One MP who advocated for explicit inclusion of sexual orientation in the initial Human Rights Act, Gordon Fairweather, resigned his seat shortly after the Act came into force to become the first Chief Commissioner of the Canadian Human Rights Commission. In his first Annual Report to Parliament, Fairweather underlined a serious problem: that the provision listing the prohibited grounds of discrimination was under-inclusive and therefore undermined the Commission's statutory mandate to promote and protect equality rights. In his report, Fairweather noted that this mandate required the extension of human rights protections to LGB individuals, saying that "[w] hatever one's views are on the propriety of ... sexual preference ... it must still be acknowledged that persons who are denied equality of opportunity on the basis of their sexual orientation are being discriminated against." 119 Fairweather would repeat this recommendation annually until he left the Commission in 1987, by which point it had become a standard plank in the Commission's annual policy recommendations to Parliament.

Fairweather's point was at least partially vindicated in 1986, when the government responded to the Report of the Parliamentary Committee on Equality Rights, which had been asked to conduct a sweeping review to ensure that Federal legislation complied with section 15 of the Charter. After noting that Committee members had been shocked by the testimony of LGB individuals detailing the level of harassment, physical violence, and hate speech to which they were exposed routinely, the Committee supported Fairweather's recommendation to grant them protection under the Human Rights Act because it would "open up an expeditious and inexpensive forum for conciliation and

117. John Ibbitson, "The 'corrosive truth' behind discrimination of gay public servants," Globe and Mail (29 April 2016), online <www.theglobeandmail.com/news/politics/ the-corrosive-truth-behind-discrimination-of-gay-public-servants/article29810555>; "Justin Trudeau apologizes for Canada's program targeting LGBTQ civil servants," The Guardian (28 November 2017), online <www.theguardian.com/world/2017/nov/28/ justin-trudeau-apologizes-for-canadas-program-targeting-lgbtq-civil-servants $>$.

118. Human Rights Act, supra note 112, s 2.

119. Canadian Human Rights Commission, Annual Report 1979 (1980) at 9-10. 
conflict resolution to those alleging they have suffered discrimination ... on the basis of sexual orientation." ${ }^{120}$ Having recourse to an administrative process was important, because it relieved complainants of having to bear the substantial time commitment, material cost, and emotional toll of having to assert their human rights claims through the judicial process. Furthermore, it ensured that complaints were investigated and adjudicated in a transparent and efficient manner.

Despite the government's claim that it intended to amend the Human Rights Act to include protection for LGB individuals, it would take another ten years for Parliament to pass the formal amendment. ${ }^{121}$ During this time, the Commission ratcheted up its critique of Parliamentary inaction. Thus, in its 1991 Annual Report, the Commission made the acerbic comment that

The question of sexual orientation is perhaps the most glaring example of legislation lagging behind the social realities and the fundamental premise that all human beings are equal in their rights. Whatever one's personal outlook on these matters, it is intolerable to this Commission that adverse treatment in the provision of services or in employment on the basis of sexual orientation should apparently go unchallenged in federal law. ${ }^{122}$

Even though the statement appears in a relatively obscure Parliamentary report instead of a published judicial opinion, and despite the fact that the Supreme Court of Canada held that the Commission did not have jurisdiction to opine on the constitutionality of its enabling legislation, ${ }^{123}$ the content of the message is strikingly similar to cases like Vriend in the sense that it offers a pointed reminder to legislators of their constitutional responsibilities.

\section{B. ADMINISTRATIVE CONSTITUTIONALISM AND THE LIVING TREE}

The Human Rights Commission began exploring more creative ways to protect equality rights by interpreting its enabling legislation in the large and liberal manner. In 1983, Parliament amended the Human Rights Act to prohibit discrimination on the ground of "family status" in order to ensure that human rights protections were extended to historically marginalized family units such as common law couples, adoptive relationships, single parents, and widowed or

120. J Patrick Boyer, Equality for All: Report of the Parliamentary Committee on Equality Right (Ottawa: House of Commons, 1985) at 30.

121. Between 1979 and 1996, the year when Parliament finally passed the amendment, no less than six attempts to introduce a similar amendment failed (in 1980, 1983, 1985, 1986, 1989, 1991). See House of Commons Debates, 42nd Parl, 1st Sess, No 248 (8 December 2017) at 1040 (Hon Sheri Benson).

122. Canadian Human Rights Commission, Annual Report 1991 (1992) at 43.

123. Cooper v Canada (Human Rights Commission), [1996] 3 SCR 854, 140 DLR (4th) 193. 
divorced persons; and in 1986 the Canadian Human Rights Commission referred a complaint filed by a gay man, Brian Mossop, who alleged that his employer had discriminated against him by withholding employment benefits on the ground that he was in a same-sex relationship. ${ }^{124}$

Mossop was a translator for the Department of the Secretary of State, precisely the type of position which had provoked Parliament to limit human rights protections for LGB individuals in 1977. Mossop had applied for one day of bereavement leave after attending the funeral of his male lover's father. The Collective Agreement which governed the terms of his employment gave employees up to four days of bereavement leave if they lost a member of their immediate family, including the immediate family of a common-law spouse; however, the Agreement defined "common-law spouse" as a relationship in which the employee had been living "with a person of the opposite sex" for at least one year, had "publicly represented that person to be his/her spouse," and intended "to continue to live with that person as if that person were his/her spouse." 125 In his application, Mossop stated simply that had been absent from work in order to attend the funeral of "the father of my lover (male) of ten years, with whom I reside." 126 Had Mossop's lover been a woman, he would have automatically qualified for up to four days' paid bereavement leave, but because he was in a same-sex relationship his employer refused his application and offered him a day of "special leave" instead. Shortly afterward, Mossop filed a complaint with the Canadian Human Rights Commission, alleging that both his employer and his union had discriminated against him by negotiating and enforcing a Collective Agreement which withheld employment benefits from him on the basis that he was in a same-sex relationship. ${ }^{127}$ The Commission, acting on a large and liberal (but clearly reasonable) interpretation of the statutory provision, referred Mossop's complaint to a hearing because there was sufficient evidence to support a finding that he had been discriminated against on the basis of his family status. ${ }^{128}$

124. Constance Backhouse, Claire L'Heureux-Dubé: A Life (Vancouver: UBC Press, 2017) at $412-427$.

125. Mossop v Canada (Department of Secretary of State) (1989), 10 CHRR D/6064 at para 2.4, 89 CLLC. 17,010 (CHRT) [Mossop].

126. Ibid at para 2.3 .

127. Backhouse, supra note 124 at 414 . Backhouse notes that the government rejected the union's demand to extend benefits to same-sex couples in the last round of collective bargaining.

128. As Jody Freeman points out, denying a gay man a benefit because of his family relationships is a clear instance of discriminatory treatment on the basis of "family status." See Freeman, supra note 26 at 76 . 
At the hearing, the Commission's lawyer called a sociology professor from the University of Toronto to contextualize the legal argument about whether Mossop had been subject to discriminatory treatment on the basis of his family status. In her testimony, Doctor Eichler testified about changing cultural attitudes regarding family relationships in Canada. In light of these changing attitudes, she asserted that one should avoid an attempt to identify essential criteria or define what constitutes a family, because family relationships involved complex, but ultimately functional, interpersonal interdependencies. When asked to comment on Mossop's relationship specifically, she said:

From what I've heard this is a relationship of some standing in terms of time with the expectation of continuance. So it's not a relationship that's defined in terms of time. You have the joint residence, you have economic union in many ways as expressed by the fact that the house is jointly owned, that life insurance- the people, the two partners are beneficiaries - that there's joint financing, it's a sexual relationship, housework is shared and it's an emotional relationship which is a very important aspect of familial relationships. ${ }^{129}$

When the adjudicator, a Toronto Lawyer who was one of the founders of the Women's Legal Education and Action Fund (LEAF), ${ }^{130}$ considered whether the complaint could be characterized as discriminatory treatment on the basis of Mossop's "family status" under the Human Rights Act, she noted that the Minister of Justice had suggested that the term had been left deliberately open-textured. When pressed by an opposition MP in 1982 to change the draft amendment of the Act to define "family status" in greater detail, the Honourable Mark MacGuigan suggested that the existing wording of the provision was a virtue because it enabled the Human Rights Commission to interpret the legislation in light of the prevailing social context and its broader statutory mandate to ensure equal opportunities for the members of historically marginalized groups. Appearing alongside Commissioner Fairweather before the Parliamentary Standing Committee on Justice and Legal Affairs, the Minister of Justice stated "[t] hese words are being interpreted by the Canadian Human Rights Commission. We trust them to interpret and issue regulations." 131

In her decision upholding the complaint, Elizabeth Atcheson (the tribunal member) cited O'Malley for the proposition that the Act should be interpreted broadly so as to recognize "the dynamic relationship between specific words and

129. Mossop, supra note 125 at para 4.8 .

130. Backhouse, supra note 124 at 416.

131. House of Commons, Minutes of Proceedings and Evidence of the Standing Committee on Justice and Legal Affairs, 32nd Parl, 1st Sess, No 115 (21 December 1982) at 73. 
the context in which they are used."132 Alluding to the Supreme Court of Canada's recent Charter jurisprudence, she noted that "[j] ust as the Supreme Court of Canada is taking a purposive approach to the interpretation of the Canadian Charter of Rights and Freedoms ... so too is the Supreme Court of Canada, in the view of the Tribunal, taking a purposive approach to the interpretation of human rights codes based on their special nature." ${ }^{133}$ Therefore, when describing her interpretive role, she noted that

the task of the Tribunal is to select a meaning which the term "family status" is reasonably capable of bearing, and that best accords with the intention of Parliament, the object of the Act, and the scheme of the Act. The Tribunal rejects the view that it must select an exhaustive or all-inclusive meaning. The Act will be invoked in many different sets of circumstances and the term family status inherently has some scope as it cannot be said to refer to an immutable characteristic, apart perhaps from consanguinity which may itself be uncertain. The question for the Tribunal, then, is not what is the reasonable meaning, but what is a reasonable meaning, which best accords with the Act. ${ }^{134}$

Thus, she concluded that the employer's refusal to approve Mossop's application for bereavement leave constituted discrimination on the basis of "family status," because those terms "should not be confined to their historical roots, but must be tested in today's world, against an understanding of how people are living and how language reflects reality." ${ }^{135}$ In doing so, Atcheson articulated a nuanced, contextually sensitive, interpretation of "family status" that advanced the declared purposes of the Human Rights Act. ${ }^{136}$ Accordingly, she ordered that Mossop be granted a day of bereavement leave retroactively, granted him $\$ 500$ in damages, and ordered the Department of Foreign Affairs and Mossop's union to extend bereavement leave benefits to same-sex employees in the future.

The Attorney General, however, sought judicial review of the Tribunal's decision in the Federal Court of Appeal. During oral submissions, the Commission's lawyer argued that the court should exercise restraint when reviewing the Human Rights Tribunal's decision. Citing a line of case authority underpinning the doctrine of judicial deference, he argued that the court could

132. Mossop, supra note 125 at para 4.47 citing O'Malley v Simpsons-Sears Ltd, [1985] 2 SCR 536 at 546-47, 23 DLR (4th) 321.

133. Ibid at para 4.51 .

134. Ibid at para 4.67.

135. Ibid at para 4.70 .

136. Freeman, supra note 26 at 58-59, 66-67. While Freeman's analysis of "family status" extends beyond the facts presented in Mossop, her sophisticated anti-essentialist approach strongly resembles the reasoning adopted by Atcheson at first instance. 
not intervene simply because it disagreed with the Tribunal's interpretation of "family status." Instead, he asserted that the Tribunal's decision should be upheld unless it could be demonstrated that its interpretation of the Human Rights Act was patently unreasonable. ${ }^{137}$

However, the court rejected the Commission's argument for two related reasons. First, Justice Marceau noted that the doctrine of deference was limited to situations where an administrative tribunal's decision was protected by a privative clause prohibiting or constraining judicial review, and since the Human Rights Act did not include such a provision it did not apply to the Tribunal's decision regarding Mossop's complaint. ${ }^{138}$

Second, he suggested that even if deference applied in the absence of a privative clause to specialized administrative agencies with relative expertise, it would extend only to the Tribunal's findings of fact, as opposed to its interpretation of the enabling statute. Since the parties agreed on the underlying facts, but disagreed about how "family status" should be interpreted, Justice Marceau concluded that "[if] the Tribunal was not correct in its answer to the question, however understandable may have been its error, the Court has a duty to intervene." ${ }^{139}$ And in this respect, it is fair to say he disagreed with the Tribunal's purposive interpretation of the Act. While he acknowledged that the Supreme Court of Canada had instructed judges to interpret the Charter purposively, and had characterized human rights legislation as "quasi-constitutional," he stated:

There is no doubt that the courts, in giving effect to the provisions of human rights legislation, should act as liberally and as "bravely" as possible, bearing in mind that are often at stake the interests of "unpopular" groups which must be defended from majoritarian opinions. But I believe that if the courts were to adopt, in interpreting human rights acts, a "living tree" approach towards discerning new grounds of discrimination for proscription, or re-defining past meanings given to existing grounds, they would step outside the scope of their constitutional responsibilities and usurp the function of Parliament. ${ }^{140}$

While Justice Marceau acknowledged that "family status" was left undefined by Parliament, he asserted that it could not extend to familial relationships that were not otherwise legally recognized. So while it was possible to contemplate the application of the term to heterosexual common-law relationships or adoptive

137. Canada (Attorney General) v Mossop, [1991] 1 FC 18 at 33, 71 DLR (4th) 661 [Mossop, FC cited to FC].

138. Ibid at 31.

139. Ibid at 32 .

140. Ibid at 33 . 
families, he simply could not fathom it applying to a relationship like Mossop's. As he put it, "[e]ven if we were to accept that two gay lovers can constitute 'sociologically speaking' a sort of family, it is certainly not one which is now recognized by law as giving its members special rights and obligations." ${ }^{141}$ In his view, the real basis for Mossop's complaint was discrimination on the ground of sexual orientation, and in this respect he opined that Mossop should have challenged the constitutionality of the Human Rights Act directly under section 15 of the Charter instead of asking the Tribunal to interpret the Act expansively. Although he acknowledged that, generally speaking, the Human Rights Act ought to be interpreted in a constitutionally compliant fashion, he protested that the Charter was not "capable of being used as a kind of ipso facto legislative amendment machine requiring its doctrine to be incorporated in the human rights legislation by stretching the meaning of the terms beyond their boundaries." ${ }^{142}$

Undeterred, Mossop and the Commission sought leave to appeal to the Supreme Court of Canada. However, while the appeal was pending, the Commission intervened in another case that was winding its way through the Ontario courts, Haig $v$ Canada. ${ }^{143}$ A Captain in the Canadian armed forces, Joshua Birch, had launched a constitutional challenge, alleging that the exclusion of sexual orientation as a prohibited ground of discrimination under the Human Rights Act violated his equality rights under section 15 of the Charter. Shortly after advising his commanding officer that he was gay, Birch was informed that pursuant to an official policy directive of the Canadian Armed Forces, he would no longer be eligible for promotion, posting, or further military training. After being released for medical reasons, Birch sought advice about launching a human rights complaint, but when he learned that discrimination on the basis of sexual orientation was not prohibited under the Human Rights Act, he launched a Charter challenge instead. On 3 August 1992, two months after the Supreme Court of Canada heard the oral submissions in Mossop, the Court of Appeal for Ontario held in Haig that the exclusion of sexual orientation under the Act infringed section 15 of the Charter because it resulted in unjustifiable, discriminatory treatment of a historically marginalized group. ${ }^{144}$ Accordingly, it ordered that protection from discrimination on the basis of "sexual orientation" be read into the Human Rights Act with immediate effect under the constitutional supremacy

141. Ibid at 35 .

142. Ibid at 38 .

143. Haig v Canada (1992), 9 OR (3d) 495, 94 DLR (4th) 1 (CA). The Canadian Human Rights Commission had intervenor status before the Court of Appeal.

144. Ibid at para 15 . 
clause. The Federal Minister of Justice at the time, Kim Campbell, decided not to appeal the decision and stated publicly that she would sponsor an amendment to the Human Rights Act to include protection for sexual orientation.

But when the Supreme Court of Canada invited Mossop to provide supplementary written submissions about whether the exclusion of sexual orientation from the Human Rights Act violated his section 15 Charter rights, Mossop declined and requested that the Court decide the case on the basis of the evidence and submissions which had already been provided. ${ }^{145}$ In what was widely considered a setback for equality rights at the time, ${ }^{146}$ the Court dismissed Mossop's appeal. ${ }^{147}$ Like the Federal Court of Appeal, a majority of the Supreme Court of Canada held that no deference was owed to the Tribunal's interpretation of its enabling statute. However, because four members of the Court recognized that Canadian courts had afforded deference to administrative decisions involving an interpretation of the agency's enabling legislation, even in the absence of a privative clause, they did not rest their decision on this basis; ${ }^{148}$ rather, they focused their attention on whether the Tribunal could claim any expertise relative to the judiciary regarding the exposition of human rights. And in a deeply ironic passage that haunts Canadian administrative law to this day, Justice La Forest made a cavalier assertion that the Canadian Human Rights Tribunal had no relative expertise insofar as the interpretation of the Human Rights Act was concerned, saying:

The superior expertise of a human rights tribunal relates to fact-finding and adjudication in a human rights context. It does not extend to general questions of law such as the one at issue in this case. These are ultimately matters within the province of the judiciary, and involve concepts of statutory interpretation and general legal reasoning which the courts must be supposed competent to perform. The courts cannot abdicate this duty to the tribunal. They must, therefore, review

145. One scholar has hypothesized that Mossop's decision was at least partly motivated by the prohibitive cost associated with launching a Charter challenge to assert his claim to equality. See Robert Wintemute, "Sexual Orientation Discrimination as Sex Discrimination: Same-Sex Couples and the Charter in Mossop, Egan and Layland" (1994) 39:2 McGill LJ 429 at 440.

146. See e.g. Blaine Donais, "Three Strikes and Human Rights is Out: Case Comment on Canada (Attorney General) v. Mossop” (1993) 57:2 Sask L Rev 363; Wintemute, supra note 145 at 440 .

147. Mossop, supra note 10.

148. Five out of the seven justices held that, while the presence of a privative clause was relevant to determining the appropriate standard of review, it was not determinative because an administrative decision might warrant judicial deference on the ground of relative expertise. Ibid at 556 per Chief Justice Lamer (Justices Sopinka and Iacobucci, concurring); ibid at 557 per Justice L’Heureux-Dubé J, dissenting; ibid at 561 per Justice Cory, dissenting. 
the tribunal's decisions on questions of this kind on the basis of correctness, not on a standard of reasonability. ${ }^{149}$

Thus, while Justice La Forest was willing to concede that the decisions of labour boards and arbitrators did merit a considerable degree of judicial deference, judges were entitled to second-guess the decisions of human rights tribunals. ${ }^{150}$ Therefore, there was no need for him to consider the Tribunal's reasons for finding in Mossop's favour, because he could simply proceed to determine the meaning of "family status" directly by applying ordinary common law canons of statutory construction. Because Justice La Forest thought that the ordinary meaning of "family" did not include same-sex couples, he concluded that the Tribunal's decision should be quashed.

In her dissenting opinion, Justice L'Heureux-Dubé explained that because the Tribunal had been delegated by Parliament to adjudicate human rights complaints like Mossop's, judges should exercise a measure of restraint when reviewing its decision. She underlined the fact that administrative agencies like the Tribunal frequently developed what she called "a certain 'field-sensitivity' where that body is in proximity to the community and its needs." 151 Thus, she noted that "[w]here the question is one that requires a familiarity with and understanding of the context, there is a stronger argument that a higher degree of deference may be appropriate." 152 However, she was careful to point out that "courts should not blindly abandon their inherent supervisory role," because " $[\mathrm{i}] \mathrm{t}$ is one thing for a court to defer to a specialized body acting within its jurisdiction, and quite another to refuse to properly exercise its supervisory power." 153

Practically speaking, this meant that while judges were not entitled to step into the shoes of the Tribunal as the primary decision maker, their role was to ensure that that decision maker provided a reasonable justification for its decision. And when she examined the Tribunal's reasons in a detailed, but respectful, fashion she concluded that it had offered cogent basis for holding in Mossop's favour. In a passage highlighting the potential of administrative constitutionalism to bolster the constitutionality of administrative law, she stated:

Even if Parliament had in mind a specific idea of the scope of "family status," in the absence of a definition in the Act which embodies this scope, concepts of equality and liberty which appear in human rights documents are not bounded by the precise understanding of those who drafted them. Human rights codes are documents

149. Ibid at 585 .

150. Ibid.

151. Ibid at 598 .

152. Ibid.

153. Ibid at 600 . 
that embody fundamental principles, but which permit the understanding and application of these principles to change over time. ... The "living tree" doctrine, well understood and accepted as a principle of constitutional interpretation, is particularly well suited to human rights legislation. The enumerated grounds of discrimination must be examined in the context of contemporary values, and not in a vacuum. As with other such types of legislation, the meaning of the enumerated grounds in s. 3 of the Act is not "frozen in time" and the scope of each ground may evolve. $^{154}$

In short, Justice L'Heureux-Dubé concluded that the Court should uphold the Tribunal's decision, because it provided a compelling rationale which elaborated on the underlying, quasi-constitutional purpose of the Human Rights Act in light of Mossop's personal experience as a gay man working in the Canadian civil service.

\section{ADMINISTRATIVE CONSTITUTIONALISM THROUGH AVOIDANCE OF MOSSOP AND EGAN}

It is difficult to assess the precise impact of the Supreme Court of Canada's decision in Mossop because it was treated very differently by front-line decision makers and superior courts. Because the Canadian government did not appeal the Court of Appeal for Ontario's ruling in Haig that the exclusion of sexual orientation in the Human Rights Act violated section 15 of the Charter, and because Mossop had refused to recast his human rights complaint as a Charter challenge, the Canadian Human Rights Commission and many of its provincial counterparts treated Haig (not Mossop) as the controlling authority. Thus, on 5 December 1992, only a few months after Haig was released, the Alberta Human Rights Commission announced it would investigate complaints of discrimination on the basis of sexual orientation, despite the fact that its enabling legislation did not include explicit protection from discrimination on that basis. ${ }^{155}$ By doing so, the Alberta Human Rights Commission side-stepped or avoided the Supreme Court of Canada's ruling in Mossop by regarding Haig as the controlling authority on how to interpret human rights legislation in a constitutionally compliant fashion. ${ }^{156}$

154. Ibid at 621 .

155. Alberta Human Rights Commission, Equal in Dignity and Rights: A Review of Human Rights in Alberta by the Alberta Human Rights Review Panel (Edmonton: Alberta Human Rights Commission, 1994) at 71 [Alberta Human Rights].

156. One could say, following Dworkin, that while human rights agencies recognized the relatively limited "enactment force" of Mossop insofar as it applied to the specific facts of that case, they afforded more significant "gravitational force" to Haig as setting out the constitutionally compliant interpretation of human rights legislation. See Dworkin, Taking Rights Seriously, supra note 4 at 111 . 
This decision had an immediate impact, provoking the Alberta government to take the extraordinary measure of issuing a ministerial order to an arm's length administrative agency, directing the Human Rights Commission not to investigate such complaints. ${ }^{157}$ While the Alberta Human Rights Commission persisted in advocating for an amendment to its enabling legislation, the Alberta government refused to act on this recommendation saying that the issue would eventually be resolved through constitutional litigation surrounding the Vriend case. ${ }^{158}$

For its part, the Federal Human Rights Commission continued to pursue complaints on the basis of sexual orientation in the federal civil service aggressively throughout the 1990s, particularly in matters relating to public sector employment benefits. ${ }^{159}$ Only a year after the Supreme Court of Canada decided Egan - a closely divided decision in which the Court ultimately upheld the constitutionality of legislation excluding same-sex partners from receiving spousal allowances under the Old Age Security Act ${ }^{160}$ - the Canadian Human Rights Tribunal held that the systematic exclusion of same-sex couples from receiving equal employment benefits constituted unlawful discrimination. In Canada (Attorney General) $v$ Moore (No 1), the Tribunal ignored Mossop altogether, preferring to cite Haig for the proposition that it was now "crystal clear" that denial of equal employment benefits to same-sex partners amounted to unlawful discrimination and that "the inclusion of a definition of 'spouse' which excludes same-sex partners in legislation or collective agreements or regulations by the government so as to deny such benefits offends the Charter and the Canadian Human Rights Act and constitutes discrimination prohibited by both." 161 Furthermore, the Tribunal distinguished its decision in Moore from the Supreme Court of Canada's ruling in Egan, on the

157. Alberta Human Rights, supra note 155 at 71.

158. Our Commitment to Human Rights: The Government's Response to the Recommendations of the Alberta Human Rights Review Panel (Edmonton: Alberta Community Development, 1995) at 21.

159. Nierobisz, Searl \& Théroux, supra note 31 at 14; Claire Mummé, "At the Crossroads in Discrimination Law: How the Human Rights Codes Overtook the Charter in Canadian Government Services Cases” (2011) 9 JL \& Equality 103. Canadian Immigration and Citizenship seems to have followed the lead of the Human Rights Commission during this period. Audrey Macklin notes that by the early 1990s, the CIC had "tacitly conceded" that the definition of "spouse" under the Immigration Act would not withstand a constitutional challenge, and had even devised informal, non-discriminatory methods for processing immigration applications submitted by same-sex couples. See Audrey Macklin, "Public Entrance/Private Member" in Brenda Cossman \& Judy Fudge, eds, Privatization, Law, and the Challenge to Feminism (Toronto: University of Toronto Press, 2002) 218 at 250-52.

160. Egan, supra note 29.

161. Moore v Canada (Treasury Board) (1996), 25 CHRR D/351 at paras 27-28, 26 CCEL (2d) 203 (CHRT). 
basis that the government could not resort to a section 1 analysis under the Oakes test to justify its decision to refuse equal employment benefits under the Human Rights Act. So although the Supreme Court of Canada had held in Egan that the exclusion of same-sex partners from receiving spousal benefits under the Old Age Security Act was nevertheless a justifiable limit on equality rights, the Tribunal in Moore held that " $[\mathrm{t}]$ he government as employer can no more rely upon s. 1 of the Charter to justify discrimination on a ground prohibited under this Act than can a private employer who is federally regulated." 162 While these statements reveal a tactful and rationally defensible process of legal reasoning which was designed to advance the overarching objectives and purposes of the Human Rights Act, the remedial impact of the Tribunal's decision was truly remarkable-it ordered the Canadian government to prepare an inventory of all federal legislation, regulation, and directives which contained exclusively heterosexual definitions of spousal relationships to be accompanied by a proposal for eliminating these provisions. ${ }^{163}$ While the government initially resisted the Tribunal's order through the court process, these challenges were unsuccessful. ${ }^{164}$

In other jurisdictions, the case law remained more divided over whether LGB employees were protected under federal and provincial human rights legislation. On the one hand, there were decisions from human rights commissions, tribunals, labour arbitrators, and courts which took the position of the Court of Appeal for Ontario in Haig that human rights legislation must be read in a Charter-compliant fashion by reading protection for sexual orientation into the legislation; ${ }^{165}$ on the

162. Ibid at para 30 .

163. Ibid at para 38.

164. Canada (Attorney General) v Moore, [1998] 4 FC 585, 160 FTR 233.

165. Leshner v Ontario (1992), 16 CHRR D/184, 92 CLLC 17,035 (Ont Board of Inquiry); Douglas v R (1992), [1993] 1 FC 264, 98 DLR (4th) 129 (FCTD); Clinton v Ontario Blue Cross (1993), 18 CHRR D/377, 93 CLLC 17,026 (Ont Board of Inquiry) [Clinton]; Waterman v National Life Assurance Co of Canada (1993), 18 CHRR D/176, 1993 CarswellOnt 5173 (WL Can) (Board of Inquiry); Canada (Treasury Board-Environment Canada) v Lorenzen (1993), 38 LAC (4th) 29, 32 CLAS 396 (Canada Public Service Staff Relations Board); Re Canada Post Corp and PSAC (1994), 35 CLAS 469, 1994 CarswellNat 3780 (Canada Arbitration); Re Bell Canada and Canadian Telephone Employees' Association (1994), 43 LAC (4th) 172, 37 CLAS 20 (Canada Arbitration); University of Lethbridge $v$ ULFA (1994), 48 LAC (4th) 242, 39 CLAS 398 (Alberta Arbitration); Newfoundland (Human Rights Commission) $v$ Newfoundland (Minister of Employment and Labour Relations) (1995), 134 Nfld \& PEIR 66, 127 DLR (4th) 694 (NL TD); Canadian Broadcasting Corp $v$ Canadian Media Guild (1995), 45 LAC (4th) 353, 37 CLAS 449 (Canada Arbitration); Metro Toronto Reference Library $v$ CUPE, Local 1582 (1995), 51 LAC (4th) 69, 41 CLAS 177 (Ontario Arbitration); Re Treasury Board (Agriculture and Agri-Food Canada) and Yarrow (1995), 43 CLAS 309, 1995 CarswellNat 3454 (WL Can) (Canada Arbitration); Nielsen v Canada (Employment and Immigration Commission), [1997] 3 FC 920, 215 NR 208 (FCA); 
other hand, there were decisions from many of the same institutions adopting the Supreme Court of Canada's position in Mossop that such protections could not be extended in the absence of a formal statutory amendment or an express constitutional challenge. ${ }^{166}$ In one particular case, two labour arbitrators hearing the same labour grievance arrived at opposite conclusions about whether Haig or Mossop was the controlling authority. ${ }^{167}$ Much of this confusion was finally put to rest in 1996, when Parliament mustered enough votes to pass an amendment to the Human Rights Act to prohibit discrimination on the basis of sexual orientation.

But despite the fact that Canadian human rights legislation and constitutional jurisprudence were clearly beginning to tack towards the position that the Canadian Human Rights Commission had staked out as early as 1979, the Supreme Court of Canada reaffirmed the general proposition that judges should not defer to the decisions of human rights agencies insofar as those decisions concern interpretive disputes about human rights. In Berg $v$ University of British Columbia, a decision concerning a human rights complaint under the British Columbia Human Rights Act issued three months after Mossop, the Court cited Justice La Forest's opinion in Mossop for the proposition that the expertise of human rights agencies did not extend to general questions of law $^{168}$ - a point it would reinforce repeatedly throughout the 1990 s. ${ }^{169}$

\section{ADMINISTRATIVE CONSTITUTIONALISM AND THE UNITY OF PUBLIC LAW}

Canada (Attorney General) v Boutilier (1997), 65 LAC (4th) 102, 48 CLAS 559 (Canada Public Service Staff Relations Board).

166. Nielsen $v$ Canada (Human Rights Commission), [1992] 2 FC 561, 32 ACWS (3d) 620

(FCTD); Hewens v Canada (Treasury Board - Public Works) (1992), 28 CLAS 627, 1992

CarswellNat 1653 (WL Can) (Canada Public Service Staff Relations Board); Layland v Ontario (Minister of Consumer \& Commercial Relations) (1993), 14 OR (3d) 658, 104 DLR (4th) 214 (Div Ct); Clinton, supra note 165; Canada Post Corp v PSAC (1993), 33 CLAS 4, 38 LAC (4th) 333 (Canada Arbitration); Re B(A) and Colloredo-Mansfeld (1994), 23 CHRR D/328, 1994 CarswellOnt 7317 (WL Can) (Board of Inquiry).

167. Compare Canada Post Corp v PSAC (1993), 34 LAC (4th) 104, 30 CLAS 477 (Canada Arbitration) with Re Canada Post Corp and PSAC (1994), 35 CLAS 459, 41 LAC (4th) 115 (Quebec Arbitration).

168. University of British Columbia v Berg, [1993] 2 SCR 353, at 368-69, 102 DLR (4th) 665.

169. Ibid; Dickason v University of Alberta, [1992] 2 SCR 1103, at 1126-27, 95 DLR (4th) 439; Zurich Insurance Co v Ontario (Human Rights Commission), [1992] 2 SCR 321 at 338, 9 OR (3d) 224; Gould v Yukon Order of Pioneers, [1996] 1 SCR 571, at 599-601, 133 DLR (4th) 449. 
This story demonstrates that instead of being at the forefront of the movement to expand equality rights, the Supreme Court of Canada was playing catch-up when it issued its decision in Vriend on 2 April 1998. By that point, Parliament, nine out of the ten provincial legislatures, and the Yukon Territory had all amended their human rights legislation to prohibit discrimination on the basis of sexual orientation, and the Canadian Human Rights Tribunal had ordered the federal government to ensure that gay and lesbian civil servants received equal employment benefits. When one situates Vriend in this way, the majority reasoning is tinged with irony, because the Court held the constitutional right to equality required state actors to read protection against discrimination on the ground of sexual orientation into human rights legislation even though the Court had struck down strikingly similar reasoning by the Canadian Human Rights Tribunal in Mossop only five years previously. While Vriend was unfortunately necessary to counteract the Alberta government's intransigence, one should read that decision within a broader historical context in order to assess the relative contributions of superior courts and Canadian human rights agencies in advancing equality rights. In this respect, the jurisprudence produced by the Canadian Human Rights Commission and the Canadian Human Rights Tribunal ought to be considered paradigmatic similar to landmark court decisions like Vriend which enlarged protection for constitutionally guaranteed equality rights.

But in addition to supplementing the historical narrative, this story also raises important methodological and institutional questions regarding the interrelationship between legislatures, courts, and administrative agencies regarding the interpretation of constitutional values. Instead of casting constitutional law as the exclusive domain of judges who have unique access to transcendental truths about fundamental legal values, we begin to see how legislatures, courts, and administrative agencies can play supporting roles in a more complex web of public justification by providing different fora for intelligent, contextually sensitive public discourse and deliberation regarding the content and practical implications of those values. ${ }^{170}$ According to this view, administrative agencies can bolster the moral unity or integrity of Canadian public law by interpreting and adjudicating human rights disputes in a fair, proportionate, and rationally justifiable manner which merits judicial respect.

At the very least, this suggests we should reject Justice La Forest's blasé and unsubstantiated assertion in Mossop that human rights agencies have no expertise insofar as interpretive questions regarding human rights are concerned. This gross

170. Habermas, supra note 40; Dyzenhaus, “The Politics," supra note 13 at 307. 
generalization retains a surprising amount of currency in Canadian courts, and it should be debunked and discarded at the earliest opportunity. ${ }^{171}$

But the moral of the story has broader implications. It also lends support to the Supreme Court of Canada's recent ruling in Doré that judges should respect administrative decisions that strike a reasonable or proportionate balance between constitutional rights and public policy objectives even if they might otherwise disagree with the substance of those decisions. ${ }^{172}$ As Justice Abella notes in Doré, the task of balancing Charter rights with public policy objectives should be informed by a sophisticated understanding of the relevant socio-legal context. And because administrative officials are (by virtue of their role as the primary fact-finder and experience regarding the relevant law) "in the best position to consider the impact of the relevant Charter values on the specific facts of the case," 173 judges should listen carefully to the reasons offered in support of an administrative decision instead of jumping to their own conclusions. ${ }^{174}$

Of course, the recognition that judicial deference is warranted even when constitutional issues are raised does not entail that judges should defer blindly to administrative decisions. It just means that their institutional responsibility is restrained in the same way as in non-Charter cases: To ensure that administrative officials act fairly by affording individuals a meaningful opportunity to be heard, and articulate an intelligible, transparent, and justifiable legal basis ${ }^{175}$ for the outcome so as to ensure that Charter rights are subject only to such reasonable limits "as can be demonstrably justified in a free and democratic

171. See e.g. Thwaites $v$ Canada (Armed Forces), [1994] 3 FC 38 at para 28, 21 CHRR D/224 (FCTD); Pitawanakwat v Canada (Secretary of State), [1994] 3 FC 298, 78 FTR 11; Canada (Human Rights Commission) v Toronto-Dominion Bank, [1998] 4 FC 205 at para 64, FCJ No 1036; Canada (Public Service Commission) v Green, [2000] 4 FC 629 at paras 83-85, 183 FTR 161; Bigsby $v$ Alberta, 2002 ABQB 574 at para 60, 318 AR 144; Pringle v Alberta (Department of Municipal Affairs), 2004 ABQB 821 at para 34, 246 DLR (4th) 502; Nixon $v$ Vancouver Rape Relief Society, 2005 BCCA 601 at para 26, 262 DLR (4th) 360; Sketchley $v$ Canada (Attorney General), 2005 FCA 404 at para 72, 3 FCR 392; University of Saskatchewan $v$ Dumbovic, 2007 SKQB 182 at para 61, 297 Sask R 1; Alberta (Minister of Human Resources \& Employment) v Alberta (Human Rights, Citizenship \& Multiculturalism Commission), 2006 ABCA 235 at paras 17-20, 273 DLR (4th) 116; Walsh v Mobil Oil Canada, 2008 ABCA 268 at paras 44-55, 296 DLR (4th) 178; CR Falkenham Backhoe Services Ltd v Nova Scotia (Human Rights Board of Inquiry), 2008 NSCA 38 at paras 19-26, 264 NSR (2d) 281; Alberta $v$ McGeady, 2014 ABQB 104 at para 31, 585 AR 311.

172. Doré, supra note 33.

173. Ibid at para 54 [emphasis in original].

174. Ibid at para 47.

175. Dunsmuir v New Brunswick, 2008 SCC 9 at paras 47, 151, [2008] 1 SCR 190. 
society." ${ }^{176}$ Incidentally, this is the same method Canadian courts employ when assessing whether common law doctrine is constitutionally compliant. ${ }^{177}$ Thus, by subjecting administrative decisions to reasonableness review, the Court in Doré establishes a uniform standard for assessing the constitutionality of both administrative law and common law doctrine.

Finally, this story suggests that judicial deference should extend beyond the balancing exercise to include administrative interpretations of substantive constitutional principles. Since Andrews v Law Society of British Columbia, the Court distanced itself from its Bill of Rights jurisprudence by declaring repeatedly that section 15 of the Charter enshrines the right to substantive equality. ${ }^{178}$ However, since that time the Court has repeatedly reinvented ${ }^{179}$ the analytical framework for section 15 in ways that seem to obfuscate or misconstrue the complex character of equality rights claims. ${ }^{180}$ At other times, the Court's preoccupation with conceptual analysis artificially constrains equality rights and consequently relieves state actors of the justificatory burden they might otherwise owe under section 1 of the Charter. ${ }^{181}$ As Sophia Moreau points out, attempts by the Supreme Court of Canada to articulate a single reductive definition of equality or discriminatory treatment can turn out to be both misguided and unproductive, because the normative facts which motivate such judgments are necessarily diverse and context-dependent. ${ }^{182}$ If, as she argues, it would be better for us to elucidate how different forms of unequal treatment limit deliberative freedoms in a variety of social contexts, it seems that human rights agencies are particularly well-positioned to investigate and articulate the various concrete ways in which discriminatory treatment can limit an individual's opportunities. Because their statutory mandate is to ensure that individuals have the freedom "to make for themselves the lives that they are able and wish to have and to have

176. Charter, supra note 32, s 1.

177. Doré, supra note 33 at paras 40-41.

178. Andrews v Law Society (British Columbia), [1989] 1 SCR 143 at 163-171, 56 DLR (4th) 1.

179. Jennifer Koshan \& Jonnette Watson Hamilton, "The Continual Reinvention of Section 15 of the Charter" (2013) 64 UNBLJ 19.

180. See e.g. Sophia Moreau, "The Wrongs of Unequal Treatment" (2004) 54:3 UTLJ 291 [Moreau, "The Wrongs"]; Sophia Moreau, "Equality and the Promise of Law v. Canada" (2007) 57:4 UTLJ 415; Sophia Moreau, “What Is Discrimination?” (2010) 38:2 Phil \& Pub Aff 143 [Moreau, "What Is Discrimination"].

181. See e.g. Gosselin v Québec, 2002 SCC 84, [2002] 4 SCR 429; Auton (Guardian ad litem of) $v$ British Columbia (Attorney General), 2004 SCC 78, [2004] 3 SCR 657; Moreau, "The Wrongs," supra note 180 at 318-326.

182. Moreau, "What Is Discrimination," supra note 180 at 157. 
their needs accommodated," 183 they are attuned to the essential link between equality rights and individual liberty and how those values can be undermined through different forms of direct and indirect discriminatory treatment.

Put negatively, this means one should be wary of the majority's assertion in Mouvement laïque Québécois v Saguenay that judicial deference should not extend to the substantive interpretation of constitutional rights per se. ${ }^{184}$ Put positively, it underlines how administrative law can provide a rich source of constitutional jurisprudence, ${ }^{185}$ because it can "bring into sharp relief the aspect of the right or freedom which is truly at stake in the case as well as the relevant aspects of any values in competition with it." ${ }^{186}$ By listening attentively to the manner in which administrative officials interpret constitutional values within a dynamic socio-economic context, judges are not abdicating their institutional responsibility; rather, they are discharging their responsibility by playing a supporting role within a broader constitutional framework which contemplates multiple, legitimate modes for interpreting fundamental values.

Therefore, while Blackstone was correct to argue that the legitimacy constitutional principles like due process, liberty, equality, and the rule of law are grounded in the moral convictions of the demos, one can still remain committed to the idea that there is an underlying unity to Canadian public law. But this unity is reflected by the broad public support for these constitutional values, as opposed to being the product of one particular legal institution. In other words, the unity of public law is not achieved by adhering to Blackstone's mistaken inference that judges must ultimately determine the content of constitutional principles. Thus, public lawyers should be wary of Dicey's claim (which other theorists embrace at times) that the unity of public law can only be guaranteed via an institutional hierarchy in which ordinary courts determine the content of the law, a claim that often resurfaces in common law doctrine concerning judicial review of administrative action. Instead, it is secured via a principle of legality which ensures that constitutional rights claims are investigated fairly and adjudicated in a substantively reasonable fashion. ${ }^{187}$ When understood in this way, judicial deference towards administrative decisions concerning human rights actually serves to strengthen, rather than weaken, the unity of public law

183. Canadian Human Rights Act, RSC 1985, c H-6, s 2.

184. Mouvement lä̈que Québécois v Saguenay (City), 2015 SCC 16, [2015] 2 SCR 3.

185. JM Evans, "The Principles of Fundamental Justice: The Constitution and the Common Law" (1991) 29:1 Osgoode Hall LJ 51 at 73.

186. Edmonton Journal v Alberta (Attorney General), [1989] 2 SCR 1326 at 1355-56, 64 DLR (4th) 577, Wilson J.

187. Dicey, Study of the Law of the Constitution, supra note 4 at 413-14. 
by conceiving constitutional interpretation as a collaborative project in which citizens, officials, and legal institutions share an underlying commitment to determining the meaning of constitutional principles in a contextually sensitive, fair, and reasonably justified manner. The salient point is that the unity of public law is not guaranteed by ensuring there is a formal hierarchy of institutions over which courts rule, but the quality of the fact-finding processes and substantive reasons offered in support of a particular decision. ${ }^{188}$

188. Habermas, supra note 40 at 119-20:

Communicatively acting subjects commit themselves to coordinating their action plans on the basis of a consensus that depends in turn on their reciprocally taking positions on, and intersubjectively recognizing, validity claims. From this it follows that only those reasons count that all the participating parties together find acceptable. It is in each case the same kinds of reasons that have a rationally motivating force for those involved in communicative action. By contrast, the actor who simply decides as she wishes is not concerned whether the reasons that are decisive for her could also be accepted by others [emphasis in original]. 